\title{
Gas well integrity and methane migration: evaluation of published evidence during shale-gas development in the USA
}

\author{
Patrick A. Hammond ${ }^{1} \cdot$ Tao Wen $^{2} \cdot$ Susan L. Brantley ${ }^{2} \cdot$ Terry Engelder $^{3}$ \\ Received: 14 August 2019 / Accepted: 11 January 2020 / Published online: 26 February 2020 \\ (C) The Author(s) 2020
}

\begin{abstract}
More than 1 million wells may have been completed using hydraulic fracturing techniques in the USA alone; however, there have been few case studies exploring the impacts on water resources due to methane migration. This study evaluated the results of three investigations initiated by the US Environmental Protection Agency, that were subsequently described in published studies at Dimock in Pennsylvania, Parker-Hood County in Texas, and Pavillion in Wyoming, as well as another study completed at Sugar Run in northeast Pennsylvania. In addition, earlier investigations at Shaws Corner in Pennsylvania, Jackson County in West Virginia, Garfield County in Colorado, and Bainbridge in Ohio are summarized. The most common cause of incidents was the presence of uncemented sections of production casings in wells that allowed gas migration from intermediate depths to shallow freshwater aquifers. In three cases, an inadequate depth of the primary top of cement (TOC) also contributed to impacts. Sources of methane were best identified through analyses of isotopes on samples from production casings, annular spaces, and water wells. In Dimock, some isotope signatures changed with time, after the completion of remedial actions. In Parker-Hood County, where impacts were not related to gas well activity, noble gas analyses were also needed to determine the source of gas. At Pavillion, where maximum methane concentrations in water wells were $<1 \mathrm{mg} / \mathrm{L}$, no significant impacts were documented. For all the sites, most or all of the fugitive gas incidents may have been prevented by fully cementing production casings to the land surface.
\end{abstract}

Keywords Stable isotopes $\cdot$ USA $\cdot$ Hydraulic fracturing $\cdot$ Methane migration $\cdot$ Well integrity

\section{Introduction}

Migration of stray methane gas has been at the center of the debate on the impacts caused by shale gas drilling and hydraulic fracturing activities on the quality of shallow drinking water resources. While not a regulated contaminant, methane can

Electronic supplementary material The online version of this article (https://doi.org/10.1007/s10040-020-02116-y) contains supplementary material, which is available to authorized users.

Patrick A. Hammond

patrick.hammond@maryland.gov; phammond@broadstripe.net

1 Maryland Department of the Environment, 1800 Washington Blvd, Baltimore, MD 21230, USA

2 Earth and Environmental Systems Institute, Pennsylvania State University, 2217 EES Building, University Park, PA 16802, USA

3 Pennsylvania State University, 443 Deike Building, University Park, PA 16802, USA accumulate to explosive levels and cause asphyxiation in confined spaces, as well as initiate adverse chemical reactions such as the reduction of iron and manganese compounds in well water (Gorody 2012; Woda et al. 2018). In the late 1940 's, hydraulic fracturing was developed to increase production from conventional oil and gas wells. By 2002 in the Barnett Shale in Texas, USA, wells in unconventional reservoirs such as low-permeability shale were being developed using horizontal drilling and high volume hydraulic fracturing (HVHF). HVHF procedures are also used for production of hydrocarbons from other "tight" formations (sandstones, siltstones, and carbonates) and coalbeds. The US Environmental Protection Agency (US EPA 2016) reports that more than 300,000 wells may have been completed using HVHF techniques since 2000 , about half in the state of Texas.

The primary way to protect drinking water resources from gas migration during development of gas wells is to effectively cement the well casings. A typical gas well consists of conductor, surface and, sometimes, intermediate casings. After cementing each casing, a production casing is extended 
to the target formation. This last casing is usually allowed by regulators in the United States to be open to rock (uncemented) for several hundred or thousand feet (tens to several hundred meters), until a few hundred feet (commonly 61-152 m or 200-500 ft) above the target. One exception of the major producing states is Arkansas (Fayetteville Shale), which, after June 2011 required extension of the production casing and its cement to the land surface. Cement placed in the annulus between the casing and bedrock strengthens the wellbore, is intended to protect the casing against corrosion, and isolates overlying aquifers from the underlying production zone. Cement shrinkage, however, can create an unintended cement annulus. Casings may leak due to mechanical and chemical failures such as poor pipe connections, well deviation, corrosion, thermal stress, or excessive pressures during drilling, hydraulic fracturing or production; however, the most common cause of stray gas migration is uncemented or poorly cemented annular spaces (Watson and Bachu 2009).

During drilling and before cementation, gas may migrate due to underbalanced annular fluids. After cementation, methane may migrate within days or weeks, if the cement volume shrank as it sets, allowing formation of high-permeability micro-annuli and channels (Vidic et al. 2013). Even after months or years, stray gas may migrate if stress promotes circumferential fractures in the cement. Such fractures can be propagated upward by the slow accumulation of gas under pressure behind the casing. Channels can also form in cement if a casing breaks, leaks or is left uncemented. Acid treatments and acid gas may also corrode cement (Watson and Bachu 2008).

Dusseault and Jackson (2014) indicate that target zones are not necessarily the source of migrated methane in problematic wells. Most primary cement jobs are effective due to the use of high-quality cement and high hydrostatic pressures at depth producing dense cements that seal annuli, preventing annular gas flow. In addition, target zones have low regional pressures as they become depleted by production (Dusseault et al. 2014); however, many stray gas impacts have occurred prior to production from the gas wells. The source of migrated methane is frequently a "gas show" in an intermediate-depth zone that has not been adequately sealed because, for example, of permeability developed in cement due to gas entrainment, chemical reactions, physical impacts or temperature changes. In such cases, gas flows upward through the annulus and into shallow drinking-water aquifers. To remediate the problem, a "squeeze" operation is usually performed to fill the void space with material such as cement. Holes are blasted in the casing using a perforation gun, the casing is sealed off, and cement is squeezed under pressure through the perforations into the annular space.

Dusseault et al. (2014) indicate that less than $50 \%$ of secondary squeeze cementation jobs of shallow and intermediate formations fail, a rate they attribute to low quality cements that result in poor seals. In addition, Wojtanowicz et al. (2001) suggested that they may fail due to the difficulty of getting full circumferential coverage in the annular spaces during injection of cement from wellbores through perforations. Venting of a gas well is also used sometimes to reduce or eliminate methane migration, which leads to undesirable gas emissions to the atmosphere.

Regional studies have shown that water wells are only impacted infrequently by development of gas wells with HVHF. Those studies generally investigate single samples from multiple water wells or regulatory databases across large areas. Such broad studies (e.g., Siegel et al. 2015) often show little correlation between the location of shale gas wells and water quality incidents; however, spatially resolved studies of the same datasets show that incidents may be identified within the broader datasets ( $\mathrm{Li}$ et al. 2016, 2017; Wen et al. 2018). Thus, while these studies successfully demonstrate broad trends, they cannot definitively document spatial and temporal changes at site-specific levels. The present study reviews the scientific literature for case histories that can demonstrate how methane migration is related to gas well construction. Despite the large number of HVHF wells drilled to date, there are few sites with detailed investigations of stray gas migration that have been published.

Although the site investigations published to date are few in number, they have incorporated many advanced forensic techniques that were not always available for investigations of earlier incidents, some of which occurred before the advent of modern techniques of HVHF, such as those in Shaws Corner, Crawford County, PA; the Parson's well, Jackson County, West Virginia (WV); Mamms Creek, Garfield County, Colorado (CO); and Bainbridge Township, Ohio $(\mathrm{OH})$. These incidents are described in the electronic supplementary material (ESM). Three of the better studied sites have been extremely well publicized in public media and investigated by the US EPA: incidents at Dimock, Susquehanna County, Pennsylvania (PA), in 2011; Parker County, Texas (TX), in 2010; and Pavillion, Fremont County, Wyoming (WY), in 2008. A large amount of valuable data was collected by the US EPA, state agencies and oil and gas operators; however, the US EPA never published final reports. Since 2011, multiple peer-reviewed papers have been published about those cases but often reached different conclusions, especially about the source of any migrated methane. This report will present a review of the results of each of those studies, with independent interpretations of the data collected at each site. The results of an additional case in Sugar Run in Bradford County, PA, will also be presented because of the large dataset available for that site. (Note: This site is not the Sugar Run in Lycoming County recently discussed by Woda et al. 2018). Figure 1 is a map of the United States showing the locations of these sites. 


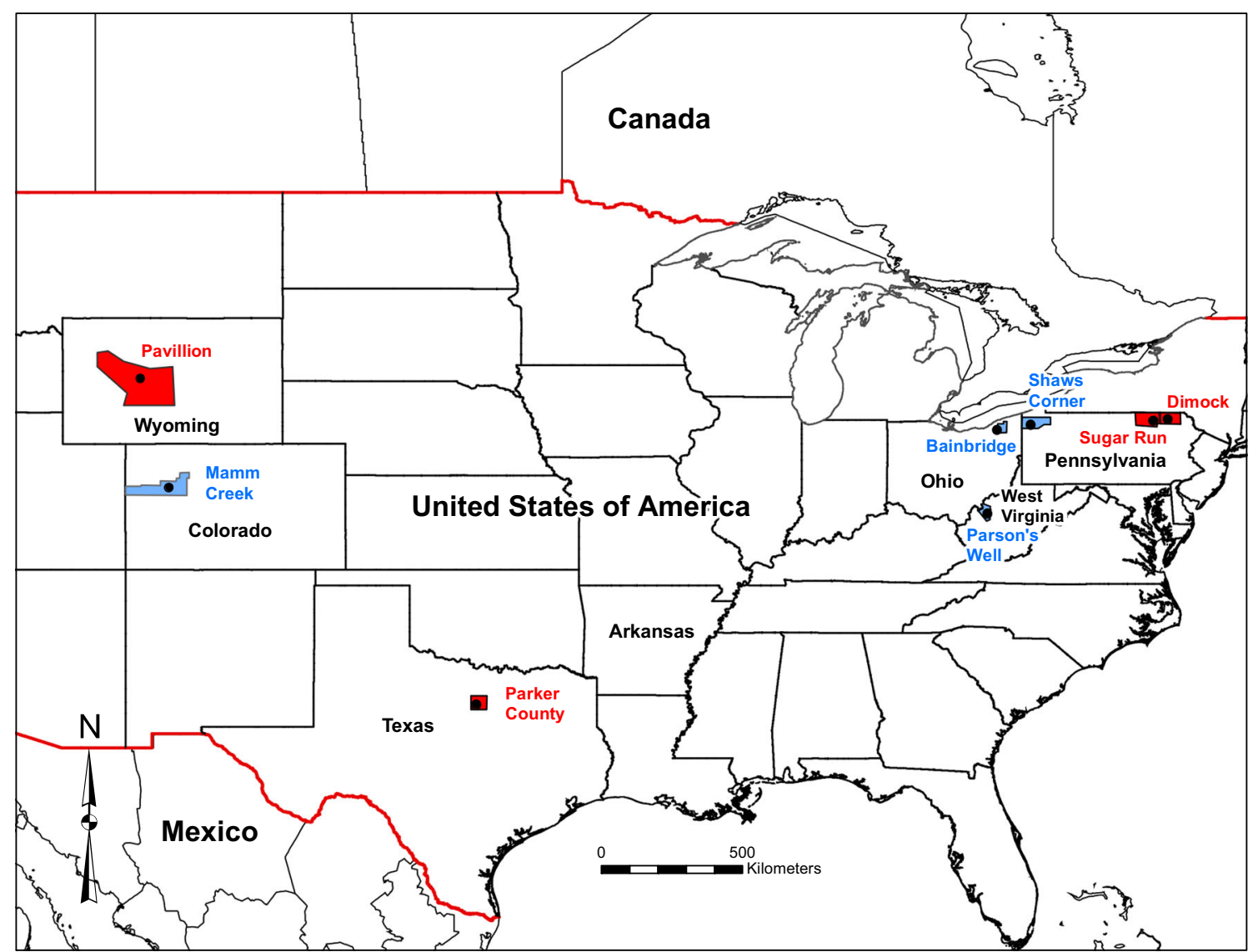

Fig. 1 Location map. The blue features are where incidents included in the ESM are located: Crawford County, Pennsylvania (Shaws Corner); Geauga County, Ohio (Bainbridge Township); Jackson County, West Virginia (Parson's well) and Garfield County, Colorado (Mamm Creek). The red features are where the case studies in the main text are located:

\section{Case study: Dimock, Pennsylvania}

\section{Case study overview}

Dimock, a small town in Susquehanna County, northeastern Pennsylvania, received international attention as incidents of methane contamination of water wells in 2009 were publicized. Osborn et al. (2011) presented evidence that methane contamination of drinking water wells was associated with shale-gas extraction within $1 \mathrm{~km}$ of water wells, with about half of samples collected in the Dimock study area. The authors suggested the most likely gas migration mechanism was leakage through gas-well casings, from either the Marcellus (Pennsylvania) and/or underlying Utica shale (New York) formations. A contrasting view was promoted by Molofsky et al. $(2011,2013)$ who assessed samples taken from about 1,700 "predrill" samples from water wells in Susquehanna County, including Dimock Township. Because of the prevalence of hydrocarbon development in Pennsylvania, such datasets not only yield data for "pre-drill" water chemistry but also yield data for water after drilling of earlier gas wells. Data they
Susquehanna County (Dimock) and Bradford County (Sugar Run), Pennsylvania; Parker County, Texas (Parker County) and Fremont County, Wyoming (Pavillion). Basemap from: Ersi, Garmin, OpenStreetMap contributors, and the GIS community

presented for wells in the Dimock study area were not included in their statistical analyses, and no specific locations were published for individual analyses. The average concentration of their water samples was $0.7 \mathrm{mg} / \mathrm{L}$, while $3 \%$ exceeded the warning level of $10 \mathrm{mg} / \mathrm{L}$ and only $0.2 \%$ exceeded the immediate action level of $28 \mathrm{mg} / \mathrm{L}$. The action levels are from Eltschlager et al. (2001). The authors indicated that methane was common in shallow groundwater and that methane concentrations correlated with surface topography, but not with proximity to existing gas wells. In 2012, the US EPA collected samples from 59 house wells in the Dimock area, and reported methane concentrations $\geq 28 \mathrm{mg} / \mathrm{L}$ in five samples $(8.5 \%)$ and an average was $9.0 \mathrm{mg} / \mathrm{L}$ (US EPA 2012).

Hammond (2016) summarized the changes in the temporal and spatial variations of concentrations, and isotopic characteristics of methane and ethane in 18 water wells as related to specific activities during gas well development at eight pads (13 gas wells) about 1 mi southeast of Dimock (Fig. 2). The Upper Devonian sandstones of the Catskill Formation are the primary aquifer for local water wells. The siliceous Union Springs Member of the Middle Devonian Marcellus 
Fig. 2 Geologic map of study area one mile southeast of Dimock, Susquehanna County, Pennsylvania (reproduced from Hammond, 2016)

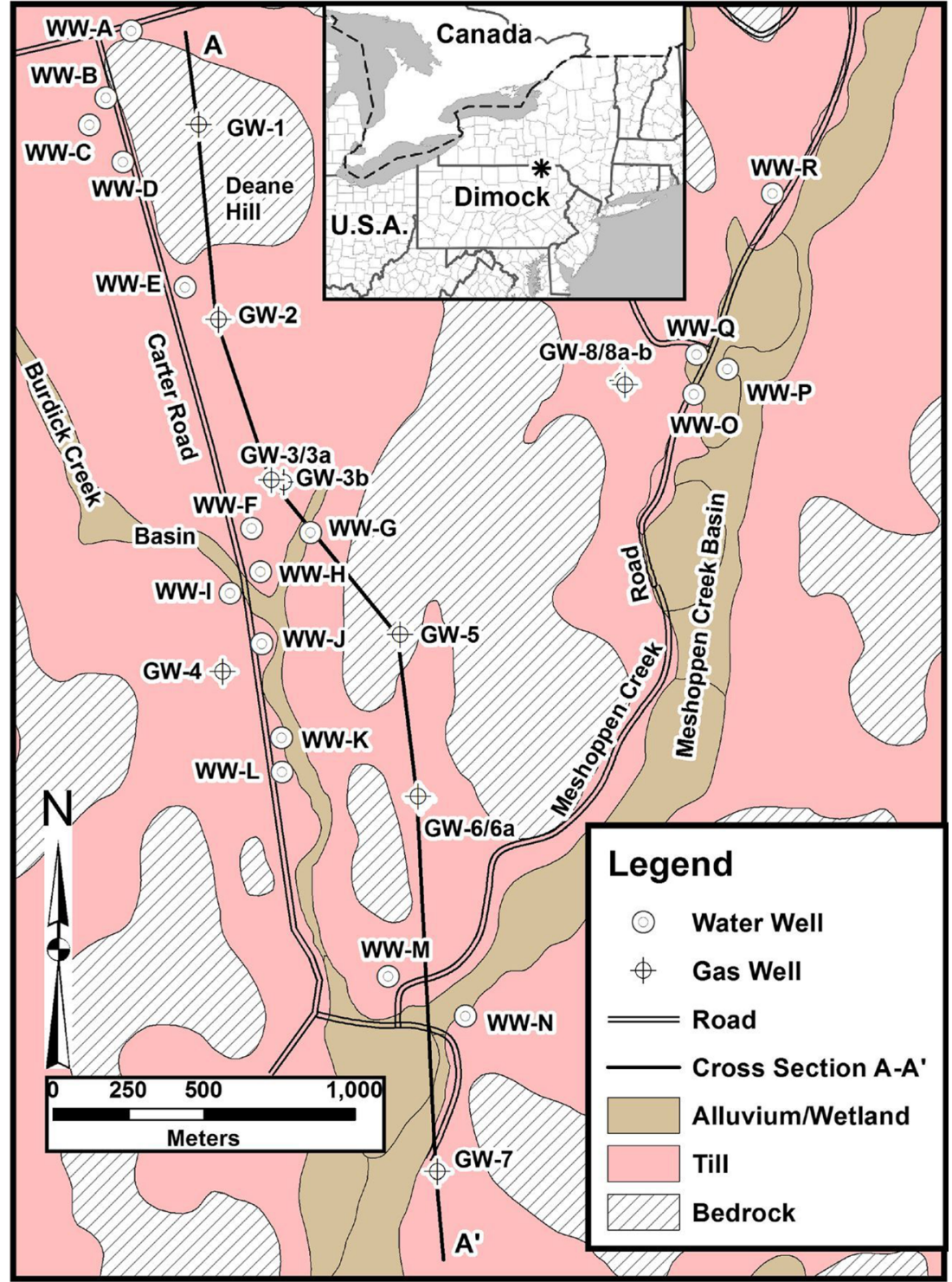

Formation is the primary target of shale-gas exploration in the study area. Gas shows are present in other, but nonproducing, Middle Devonian Formations at intermediate depths.

In some cases, "geochemical fingerprinting" can be used to identify methane sources by analyzing carbon and deuterium isotopes of methane (Schoell 1983). Thermogenic methane $\left(\mathrm{CH}_{4}\right)$ originates from the burial of organic sedimentary matter at high temperatures; while biogenic methane is produced by either bacterial fermentation or from the bacterially-mediated reduction of carbon dioxide. The use of the isotope ratios of $\delta^{13} \mathrm{C}-\mathrm{CH}_{4}\left(\delta^{13} \mathrm{C}_{1}\right)$ in combination with the ratios of $\delta^{2} \mathrm{H}-\mathrm{CH}_{4}$ $\left(\delta \mathrm{DC}_{1}\right)$ can sometimes distinguish the two different sources. There are complications to the interpretation of sources using $\delta{ }^{13} C_{1}-\delta D C_{1}$ data (Baldassare et al. 2014).

Isotope analyses were reviewed for samples taken from gas and water wells in the study area and are shown in a Schoell diagram, Fig. 3. The first samples were collected by the Pennsylvania Department of Environmental Protection (PA DEP) in 2009 from gas well annular spaces and water wells along Carter Road, prior to any remedial actions (Hammond 2016). Follow-on samples were analyzed by the PA DEP and the operator's consultant, Civil and Environmental Consultants, Inc. (CEC), in 2010, and the US EPA in 2012. In addition, PA DEP and the operator analyzed samples taken from production casings and a gas pipeline. The 2009 data for five water wells and the annular spaces of three gas wells are contained in one cluster, while there is a second cluster consisting of the data for the more enriched production gas samples. The low concentration $(<10 \mathrm{mg} / \mathrm{L})$ of the 2012 US EPA samples are generally more isotopically enriched than the 2009 results, while the higher concentration samples are generally more depleted. The 2010 samples have relatively high concentrations and tend to 
Fig. 3 Schoell diagram of methane gas samples in the study area analyzed by the PA DEP, CEC, the US EPA and the operator. B: Bacterial (microbial) gas; M: Mixed gas; TO: Oil associated thermogenic wet gas; TC: condensate associated thermogenic wet gas; and TD: Dry thermogenic dry gas. The figure is adapted from Hammond (2016), is modified to include Mud Gas Log (MGL) mean values from Baldassare et al. (2014): 1 Marcellus Shale, 2 Hamilton Group (Mahantango Shale), 3 Tully Limestone, 4 Geneseo Shale, 5 Brallier Formation, and 6 Catskill/Lockhaven Formations. Water well samples are noted as WW and gas wells as GW

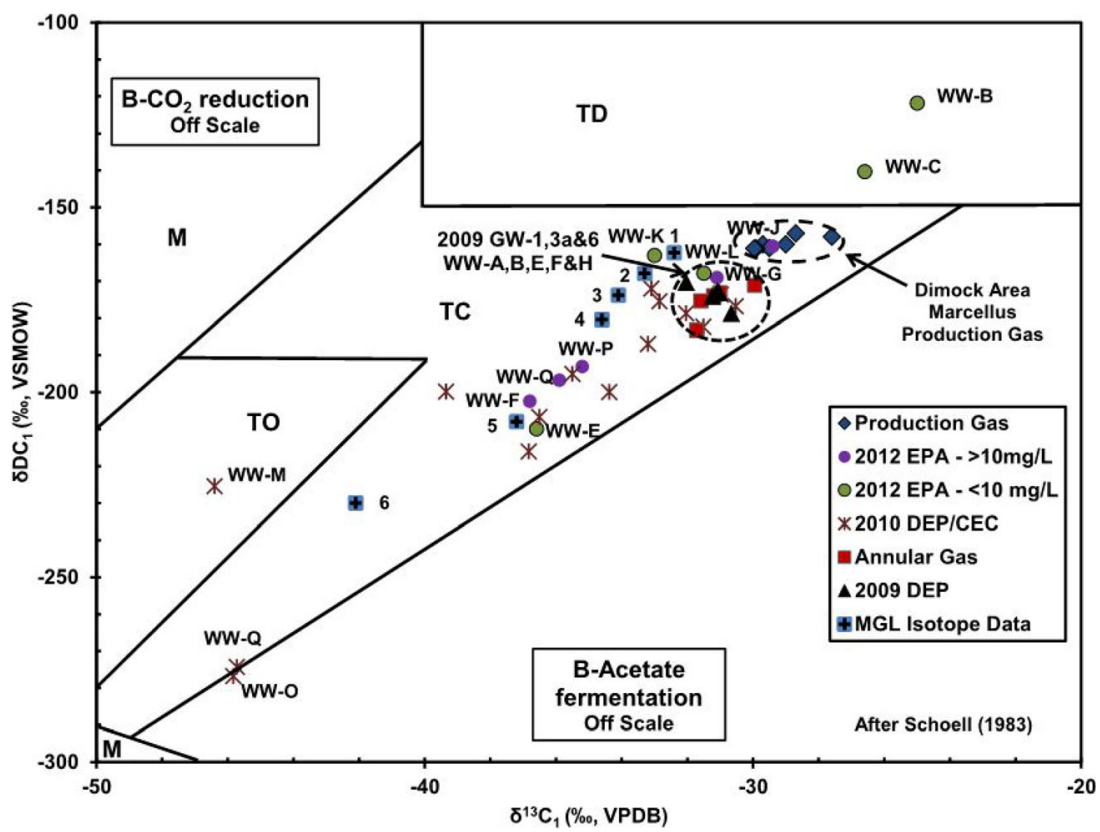

be similar to or more isotopically depleted than the 2009 data.

Baldassare et al. (2014) analyzed isotopes in samples collected during mud gas logging (MGL) programs in northeastern Pennsylvania. The trend of the MGL data matches that of the Dimock data, although offset in $\delta^{13} \mathrm{C}_{1}$ by about $2-3 \%$. These results indicate that the source of methane for the 2009 samples could be the intermediate-depth formations immediately above the Marcellus Shale (either or both of the Middle Devonian units (Mahantango Shale and Tully Limestone). As described by Hammond (2016), samples collected after 2009 and the completion of gas well remediation efforts often showed microbial alteration or evidence of a microbial source as summarized in the ESM. Some of these samples are discussed in the following.

\section{Gas well 1 (GW-1) methane migration and well operations}

Gas well GW-1 was drilled to 2,271 m and completed on August 31, 2008 (Fig. 4). The intermediate casing was set and cemented between land surface and $468 \mathrm{~m}$. The depth of the primary top of the cement (TOC) was in the Purcell Limestone at 2,164 $\mathrm{m}$ or only $9 \mathrm{~m}$ above the top of the Lower Marcellus Shale. Although there is no record, this indicates that circulation may have been lost at that depth or drilling mud did not return to the surface, due to the potential secondary porosity and permeability of the limestone member. The cement was described as either absent or "ratty" above that depth, indicating that there was nearly $1,700 \mathrm{~m}$ of an open borehole across the Mahantango Shale. Therefore, gas in the Mahantango Shale, where $17 \mathrm{Mm}^{3} /$ day of gas condensate were measured to be flowing at $1,801 \mathrm{~m}$, could have migrated upward to nearby house wells. The completion report for GW1 indicated that there was a gas show at 2,099 m, which was also above the primary TOC.

The problem of cloudy water in house well WW-B was first noted about 2 weeks after completion of the GW-1 (September 12, 2008), but prior to remediation and hydraulic fracturing of that well. The low \% LEL readings $(<1 \%)$ in WW-B (October 15, 2008) and WW-C (November 10, 2008) were likely due to low or intermittent water use from both wells or unrecorded venting of GW-1. On the same dates as the \% LEL levels rose above predrill levels, the Fe concentrations $(6.9$ and $3.88 \mathrm{mg} / \mathrm{L})$ were elevated in both wells relative to pre-drill concentrations $(0.011$ and $0.03 \mathrm{mg} / \mathrm{L})$. Such concentrations can result from the reduction of Fe compounds by bacteria using methane as an electron source and typically last for a limited time period (Woda et al. 2018); they may provide evidence that methane had migrated prior to hydraulic fracturing of GW-1. GW-1 was then squeezed at 2,091 m, $1.2 \mathrm{~m}$ below the top of the Upper Marcellus Shale on October 22, 2008, producing a secondary TOC, above the primary TOC, at $1,673 \mathrm{~m}$. No data indicating that the squeeze was successful were reported. Indeed, the Fe concentration remained elevated at $3.88 \mathrm{mg} / \mathrm{L}$ in WW-C on November 10 , 2008.

GW-1 was hydraulically fractured in the Lower and Upper Marcellus between November 9, 2008 and November 10, 2008, and between November 10, 2008 and November 11, 2008 , respectively. The water-well pump vault for WW-A is believed to have sustained a methane explosion on January 1, 2009 (Engelder and Zevenbergen 2018). A few weeks later (January 27, 2009), the pressure in the GW-1 $(11.4 \mathrm{~cm} \times$ 


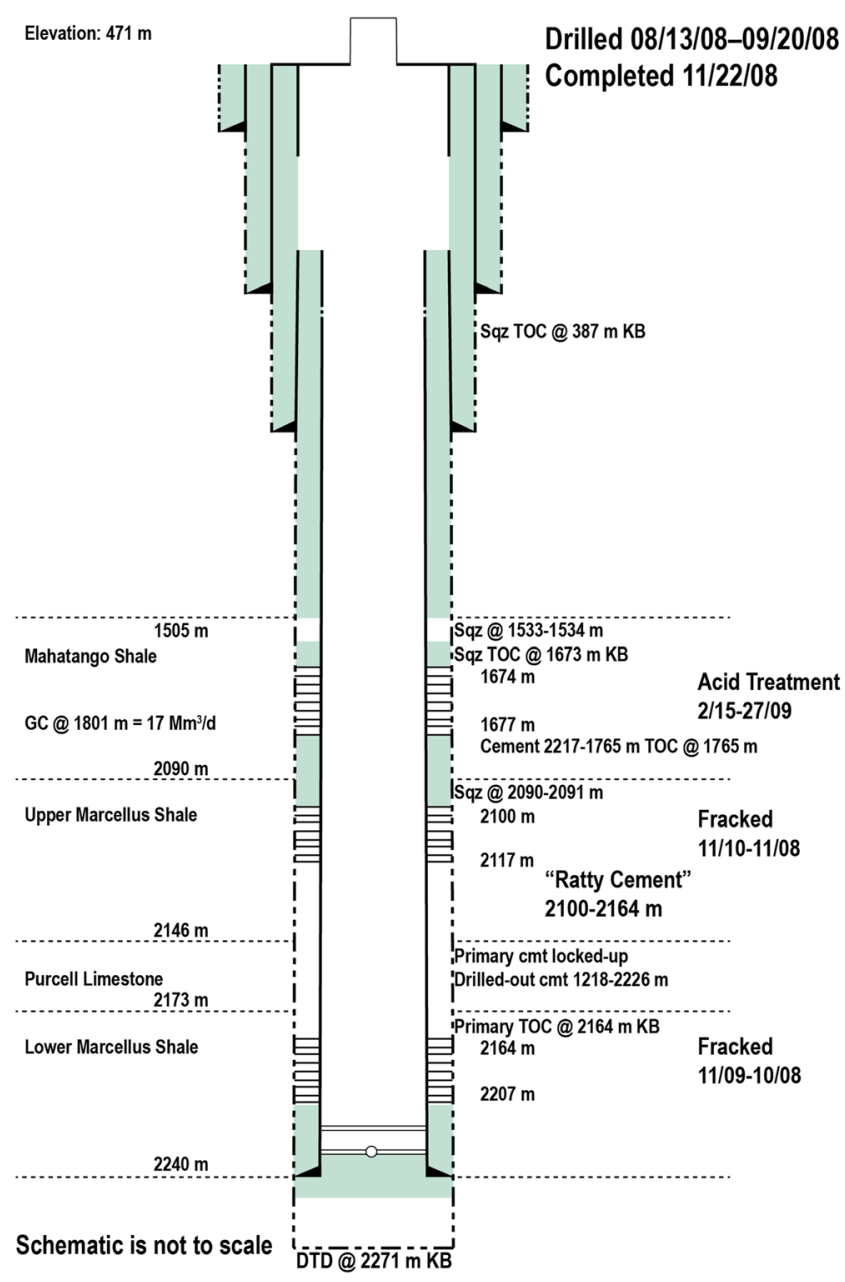

Fig. 4 Construction schematic of gas well GW-1 in the Dimock study area. Well construction details from Watson (2010)

$17.8 \mathrm{~cm}$ annulus) was $3,585 \mathrm{kPa}$ (520 psig). On January 8, 2009 , the $\delta^{13} C_{1}$ and $\delta D_{1}$ isotopes for the GW-1 annular space gas were -31 and $-173 \%$, respectively, while the $\delta^{13}$ $\mathrm{C}_{1}$ and $\delta \mathrm{DC}_{1}$ isotopes in nearby WW-B on January 12,2009 were -31 and $-179 \%$, respectively. These data are nearly identical, suggesting that the methane in WW-B migrated from the annulus of GW-1. The gas company tried several remediation attempts on GW-1. The well was: (1) squeezed in the interval 1,533-1,534 m on February 10, 2009; (2) acid treated on February 15, 2009 the Mahantango Shale (1,6161,674 m); (3) plugged between April 292010 and May 7, 2010 ; (4) reentered so that the cement could be drilled out to $474 \mathrm{~m}$ and (5) replugged on June 16, 2010. After that, on January 26, 2012, methane levels in WW-B and WW-C declined (1.7 and $3.8 \mathrm{mg} / \mathrm{L}$, respectively) and no Fe was detected in either well. At that time, the isotopes in each well were enriched relative to the 2009 water well and annular space values, probably as a result of microbial oxidation (ESM). Also, there was either no cement or only a poor seal between the top of the Lower Marcellus Shale and the perforation for the squeeze at the top of the Upper Marcellus Shale. Although it cannot be determined from the available information, hydraulic fracturing, especially of the Upper Marcellus Shale, could have damaged this squeeze cement seal.

\section{Gas well 3a (GW-3a) methane migration and well operations}

Prior to construction of three gas wells (GW-3, GW-3a, GW $-3 \mathrm{~b})$, no methane was detected in three house wells within $457 \mathrm{~m}$ of the gas wells. On January 14, 2009 and January 18, 2009, high methane levels of 43, 43, 31 and $48 \mathrm{mg} / \mathrm{L}$ were measured in WW-F, WW-G, WW-H and WW-I, respectively. The history of these three wells is described below.

GW-3 was drilled to a depth of $271 \mathrm{~m}$ and GW-3b was completed to a depth of $582 \mathrm{~m}$. Both were conventional wells and neither was hydraulically fractured. GW-3 was plugged, drilled out then re-plugged to total depth, because the drill string was stuck in the well bore. GW-3b was plugged on May 23, 2010.

GW-3a was drilled to a vertical depth of 2,124 m. $25.5 \mathrm{Mm}^{3} /$ day of gas was measured to be flowing at $475 \mathrm{~m}$, so an intermediate casing was installed from land surface to $510 \mathrm{~m}$ and cemented. There was an open-hole (uncemented) production casing section of $1,103 \mathrm{~m}$ to the TOC at $1,613 \mathrm{~m}$ (411 m above first perforation). GW-3a was not hydraulically fractured until March 20, 2009, several months after high methane levels were observed in nearby water wells. GW-3a was subsequently plugged on May 23, 2010. Although there were no other gas shows in the well, a pressure of $1,944 \mathrm{kPa}$ (282 psig) was measured in the annulus of GW-3a on January 26,2009 , requiring a squeeze cement job to be performed on that well on April 3, 2009 to April 5, 2009.

Prior to squeezing and/or plugging of GW-3a and GW-3b, methane concentrations in four water wells (WW-G, WW-H, WW-I, WW-F) varied from 19 to $44 \mathrm{mg} / \mathrm{L}$ and little to no change was observed after remediation. Specifically, after plugging of $\mathrm{GW}-3 \mathrm{a} / \mathrm{GW}-3 \mathrm{~b}$, the average concentration in WW-G was $33.9 \mathrm{mg} / \mathrm{L}$, methane levels in WW-H and WW-I varied from 29 to $61 \mathrm{mg} / \mathrm{L}$, and six measurements in WW-F ranged from 2.5 to $18.3 \mathrm{mg} / \mathrm{L}$ (average of $11.3 \mathrm{mg} / \mathrm{L}$ ).

Isotopic analyses of the samples from WW-F and WW-H corroborated the lack of effectiveness of the remediation. Specifically, samples taken before remediation (January 21, 2009) showed values consistent with the Mahantango Shale as measured in samples taken from the annular spaces of GW3a. After remediation, there was little change in the isotopic signatures for WW-G, WW-H and WW-I; however, the sample WW-F was substantially more depleted than the annular space gas. These concentration and isotope data indicate that remediation of $\mathrm{GW}-3 / \mathrm{GW}-3 \mathrm{a} / \mathrm{GW}-3 \mathrm{~b}$ may have mitigated some of the impacts to WW-F, but had little or no effect on WW-G, WW-H and WW-I. 


\section{Conclusions for the Dimock case study}

The number of water wells in the Dimock study area exceeding the hazard limits for methane was much greater than would be expected relative to regional background levels in Molofsky et al. (2011, 2013): this is evidence that the gas well activity caused the incidents. Isotopic signatures of water from wells sampled in 2009 were similar to those measured from gases from annular spaces in gas wells at intermediate depths above the Marcellus, but not with Marcellus production gases. Thus, leakage into the wellbore through failed casing cement seals are the most likely cause of methane migration. Remediation by squeeze cementing only partially mitigated the impacts. Consistent with previous interpretations (Darrah et al. 2014; Jackson et al. 2013; and Hammond 2016), all of the samples from water wells in the study showed evidence of some thermogenic methane based on isotopic signature. Samples collected after 2009 generally had isotopic signatures showing a thermogenic signature, several which had overprints of bacterial effects. In several cases where remediation caused a substantial reduction in methane levels, there were also substantial changes in the isotope values. This supports the Molofsky et al. (2018) suggestion that large changes in methane concentrations and stable isotopes were likely indicators of stray gas impacts.

In summary, gas well activity appears to have impacted all but one of the 18 house wells in the study around Dimock PA (Hammond 2016). Migration was probably due to leakage of methane from gas-bearing formations that were left uncemented across sections of shale-gas well production casings, in contact with gas-bearing, but unproductive, formations, upward through into the annular spaces of the boreholes. The gas likely leaked upward to below or outside of the protective surface casing, and into the aquifer supplying the residential water wells. None of the peer-reviewed studies in the Dimock study area found clear evidence of contamination by fluids injected in the fracturing process.

\section{Case study: Parker County, Texas}

\section{Previous investigations}

\section{TX RRC (2011) and Kornacki and McCaffrey $(2011,2014)$ investigations}

The study area is at the boundary between Parker County and Hood County, Texas, where the operator completed two horizontally-drilled gas wells in March 2009 (GW-2) and June 2009 (GW-1) at the same wellpad. The wells were drilled vertically to depths of almost $1,800 \mathrm{~m}(6,000 \mathrm{ft})$ and then horizontally to the northwest. GW-1 has surface casing set at

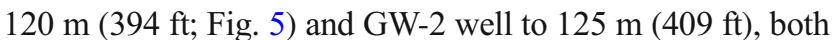

cemented to the surface, while the maximum depth of nearby water wells is $107 \mathrm{~m} \mathrm{(350} \mathrm{ft).} \mathrm{There} \mathrm{is} \mathrm{no} \mathrm{cement} \mathrm{from} \mathrm{the}$ bottom of the surface casing until 1,396 $\mathrm{m}(4,580 \mathrm{ft})$ and $1,466 \mathrm{~m}(4,810 \mathrm{ft})$ for GW-1 and GW-2, respectively. This produced a primary cement barrier which was $380 \mathrm{~m}$ $(1,247 \mathrm{ft})$ above the uppermost producing interval, $1,776 \mathrm{~m}$ $(5,827 \mathrm{ft})$, in GW-1. After hydraulic fracturing stimulation, they started producing gas in August 2009 from the Barnett Shale.

In August 2010, a homeowner filed a complaint with the Railroad Commission of Texas (TX RRC), which has jurisdiction over oil and gas wells in Texas, and the US EPA, which has federal jurisdiction over underground sources of drinking water (USDW), about methane contamination in his water well (DW-1), alleging that methane migrated from the two gas wells, located about $150 \mathrm{~m}(500 \mathrm{ft})$ from his well. The operator collected water samples from the domestic water well DW-1 and 22 other water wells in the neighborhood and gas samples (casing head) from the gas wells in late 2010 and early 2011. The measured methane concentration in the DW-1 sample collected on August 26, 2010 was $2.3 \mathrm{mg} / \mathrm{L}$; however, most samples were collected after filtration and aeration, needed to remove dissolved sulfide, suggesting that this was a minimum concentration (Thyne 2015).

In August 2010, the pressure was $207 \mathrm{kPa}$ (30 psi) on the GW-1 bradenhead (production-surface casing annular space) and there was no bradenhead pressure in GW-2, the usual indication that methane gas was not leaking from the vertical open-hole portions of the gas wells. When a mechanical integrity test was performed on GW-1, the pressure was $5,825 \mathrm{kPa}(845 \mathrm{psi})$ and no leakage was found from the production casing. Cement bond logs completed for both wells showed good cementation for those intervals with cement.

On August 8, 2010, a contractor for the homeowner sampled DW-1 and found a methane level of $7.8 \mathrm{mg} / \mathrm{L}$ and the presence of higher-order hydrocarbons and volatile organic compounds (VOCs). The presence of VOCs was also found in another domestic well (DW-2), but there was no methane. On October 26, 2010, the US EPA sampled DW-1, producing a methane concentration of $20.1 \mathrm{mg} / \mathrm{L}$ and an isotopic signature $\left(\delta^{13} \mathrm{C}=-47.1 \%\right.$ and $\delta \mathrm{D}=-188.5 \%$ o $)$ that was similar to those of the gas wells $\left(\delta^{13} \mathrm{C}=-46.6 \%\right.$ and $\delta \mathrm{D}=-183.9 \%$ ) . Based on the methane concentrations and isotopic signatures, and the presence of VOCs, the US EPA issued an Emergency Administrative Order on December 7, 2010, which required monitoring of water wells within $910 \mathrm{~m}(3,000 \mathrm{ft})$ of the gas wells, performance of soil and air gas surveys, and the submittal of a remediation plan.

At a TX RRC hearing in 2011 (TX RRC 2011), the Strawn Group was identified as the source of the methane, not the underlying Barnett Shale supplying the gas wells, based on the nitrogen and carbon dioxide content of casing head gas in DW-1 (Kornacki and McCaffrey 2011, 2014). In addition, the 


\section{Parker County GW-1}

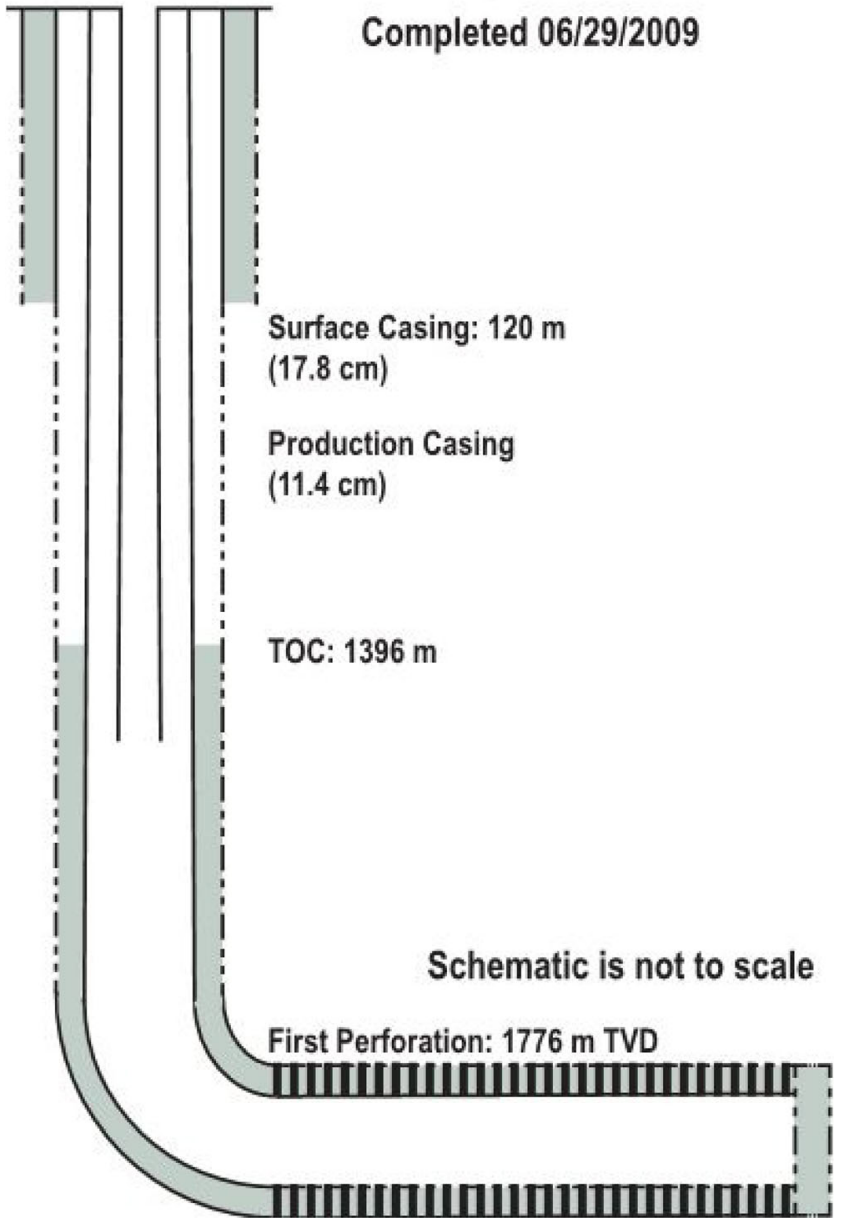

Fig. 5 Construction schematic of gas well $1(\mathrm{GW}-1)$ in the Parker-Hood County study area. Well construction details from Pope (2012)

bradenhead gases had microbial isotopic signatures, indicating that thermogenic gas of the from either the Strawn Group or Barnett Shale did not leak upward behind the production casing, unless it bled off or drained through an intermediate permeable formation or a structural feature (e.g. fault, joints, or fractures). While this may occur in the unconsolidated Cenozoic sediments of the Texas Gulf Coast, it is less likely to occur in the low-permeability consolidated Mesozoic/ Paleozoic sedimentary rocks of Parker County. Finally, the TX RRC suggested that increased water use and a significant drop in the water level after a new house was built on the property could have resulted in dissolved gas exsolution, producing the elevated methane levels.

The US EPA withdrew its order as the TX RRC had jurisdiction over oil and gas activities in Texas, but continued to maintain that the source of the methane was the gas wells. After further problems were reported and a second investigation completed, the TX RRC determined the source of the methane was uncertain, after the $\mathrm{N}_{2}$ data were corrected for atmospheric contribution using Ar content (Table 3 in Pope 2014).

\section{Darrah et al. (2015) investigation}

Darrah et al. (2015) used noble gas and hydrocarbon tracers to distinguish natural sources of methane from anthropogenic contamination and to determine what mechanisms caused elevated light hydrocarbon concentrations in drinking water wells near natural-gas production wells.

Noble gases are ideal tracers of crustal fluid processes because they are nonreactive with other chemical elements or compounds and have distinct isotopic compositions in the crust, hydrosphere, and atmosphere. In most sedimentary aquifers, noble gases are a mixture of air saturated water of an atmospheric origin and those produced by radioactive decay of elements such as U, Th and ${ }^{40} \mathrm{~K}$ in the Earth's crust. Noble gases incorporated into crustal fluids fractionate by mechanisms such as diffusion and phase partitioning. When paired with hydrocarbon composition and inorganic water chemistry, noble gases then can help differentiate between natural geological migration of hydrocarbon gases and anthropogenic contamination, and the mechanisms by which anthropogenic gas contamination occur.

Darrah et al. (2015) analyzed 20 samples collected from drinking-water wells drilled into the Trinity Aquifer overlying the Barnett Shales in the study area, for hydrocarbon concentrations and isotopic compositions (e.g., $\mathrm{C}_{2} \mathrm{H}_{6} / \mathrm{CH}_{4}, \delta^{13} \mathrm{C}$ $\mathrm{CH}_{4}$ ) and providing comprehensive analyses of noble gases and their isotopes (e.g. ${ }^{4} \mathrm{He},{ }^{20} \mathrm{Ne},{ }^{36} \mathrm{Ar}$ ) in groundwater near shale-gas wells. ${ }^{20} \mathrm{Ne}$ and ${ }^{36} \mathrm{Ar}$ in groundwater are mostly of atmospheric origin, while ${ }^{4} \mathrm{He}$ in groundwater is mostly crustally produced. The amount of these isotopes was used to delineate the contribution of atmospheric and crustal end members for dissolved species in groundwater. They identified eight discrete clusters with elevated methane concentrations and anomalous noble gas compositions consistent with stray gas contamination, seven in the Marcellus Shale and one in the Barnett Shale.

The molecular ratio of aliphatic hydrocarbons $\mathrm{C}_{2} \mathrm{H}_{6}+/ \mathrm{CH}_{4}$ (Fig. 4C of Darrah et al. 2015) and noble gases $\left({ }^{4} \mathrm{He}^{/ 4} \mathrm{Ar} *\right.$ and ${ }^{4} \mathrm{He} /{ }^{20} \mathrm{Ne}$; Fig. 4D of Darrah et al. 2015) in samples with evidence of fugitive gas contamination are significantly greater than other natural groundwaters in the area. (Note that a star ' $*$ ' is commonly used to indicate a noble gas component from a crustal end member.)

Their initial sampling in December 2012 revealed that 9 of 12 Barnett study area groundwater samples were similar to the normal trend (i.e., uncontaminated groundwater impacted by the deep gas-rich brine that migrated over geological time) in samples from their Marcellus study area. In the Marcellus study area, all normal ${ }^{36} \mathrm{Ar}$ trend samples both $>1 \mathrm{~km}$ and $<1 \mathrm{~km}$ from drill sites had an $\mathrm{N}_{2}$ that varied within $\sim 15 \%$ of 
the temperature-dependent air-saturated water solubility line (Darrah et al. 2015). Two additional resamplings of 12 domestic water wells from the Barnett study area during both August and November of 2013 that included four additional domestic wells ( 8 new; 20 in total) showed no evidence of contamination.

They suggested that the data from five water wells in the Barnett study area were evidence of gas-phase migration from gas wells, whereas the methane in the remaining 15 wells occurred naturally. The initial December 2012 sampling identified three anomalous samples in the Barnett study area with supersaturated $\mathrm{CH}_{4}$ that departed from the brine-meteoric water mixing line and showed significant depletions (i.e., stripping) of all air-saturated water components $\left({ }^{20} \mathrm{Ne},{ }^{36} \mathrm{Ar}\right.$, and $\mathrm{N}_{2}$ ). The two previously normal wells that displayed increased $\mathrm{CH}_{4}$ through time also became depleted of air-saturated water gases by August 2013. The stripped air-saturated water compositions in groundwater samples occurred $<1 \mathrm{~km}$ from drill sites in the Barnett study area and were attributed (by Darrah et al. 2015) to a rapid introduction of high-pressure gas-phase hydrocarbons into shallow aquifers, most likely sourced from the Strawn Group. This was not consistent with the cases of GW-1 and GW-2, both of which had low pressures measured in their annular spaces. The lighter isotopes of stable noble gases (i.e., Ne and Ar), plus nitrogen were not preferentially stripped from groundwater samples near GW-1 and GW-2.

Because the isotopic composition $\left(\delta^{13} \mathrm{C}_{-} \mathrm{CH}_{4}\right)$ of both the Barnett Shale and overlying Strawn Group are similar, additional fingerprinting techniques such as noble gases or the molecular composition of hydrocarbons were used to determine the source of the methane and the mechanism controlling methane migration.

Darrah et al. (2015) concluded that the similarity between $\mathrm{C}_{2} \mathrm{H}_{6}+/ \mathrm{CH}_{4}$ vs. $\delta^{13} \mathrm{C}_{-} \mathrm{CH}_{4}$ and ${ }^{4} \mathrm{He} /{ }^{40} \mathrm{Ar} *$ vs. ${ }^{4} \mathrm{He} /{ }^{20} \mathrm{Ne}$ in the Strawn-produced gases and the anomalous subset of five groundwater samples in the Barnett study area suggests that contamination likely results from the release of annulusconducted gas, probably by poor cementation, sourced from the Strawn Group rather than from the Barnett Shale.

Data on the Strawn and Barnett-produced gases and potential impacts to water wells were included in Kornecki and McCaffrey $(2011,2014)$. The production wells in the Barnett study area were located in the vicinity of GW-1, GW-2, DW-1 and DW-2; however, since detailed locations were not given by Darrah et al. (2015), due to potential legal issues (T. Darrah, Ohio State University, personal communication, 2019), it cannot be determined if any samples were collected from those wells.

\section{Thyne (2015) investigation}

Thyne (2015) determined that the isotopic signature of methane in most of the Trinity Aquifer wells was thermogenic and appeared to be degraded by microbial activity. In contrast, he indicated that the methane from the gas well bradenheads has a significant biogenic component, i.e. the $\delta^{13} \mathrm{C}_{1}$ and $\delta \mathrm{DC}_{1}$ values were -62 and $-55 \%$, and -195 and $-240 \%$, for $\mathrm{GW}$ 1 and GW-2, respectively. He attributed this to biogenic carbonate reduction, commonly found at intermediate depths in sedimentary systems above the thermally mature source rocks.

Thyne (2015) indicated that the initial identification of the gas in DW-1 as being from the Strawn Group was logical. The study area is located directly over hydrocarbon deposits, including the Strawn Group, with producing horizons only a few hundred feet (less than about $100 \mathrm{~m}$ ) below the aquifer and gas could have moved across an unconformity into the Trinity Aquifer. However, he then further stated that samples from DW-1 had methane isotopic values and molecular compositions identical to Barnett gas, notwithstanding the similarity to the Strawn gases and the results of the noble gas analyses. The gas wells are located in general proximity to large geological faults in the Barnett Shale and the overlying formations. DW-1 and surrounding water wells have shown increasing concentrations with time along linear spatial trends, and the presence of higher order hydrocarbons, which he suggested was evidence of a continuous leak from a gas seep. The east-west orientation of the gas plume is consistent with the general orientations of the preexisting fault and the underlying sandstones in the Strawn Group. He suggested that the source of the methane was the Barnett Shale and that the gas was produced during hydraulic fracturing and that it migrated to the Strawn Group along an unidentified preexisting fault or a conduit produced by hydraulically induced fracturing. Frohlich (2012) indicated that there were no mapped faults at the surface or earthquakes in the area that might suggest faulting at depth. This was supported by a structure map, constructed from 3D seismic data (TX RRC 2011).

\section{Wen et al. (2016) and companion investigations}

Wen et al. (2016) collected 45 groundwater samples from 35 wells in the Trinity Aquifer within the Barnett Shale footprint in Parker and Hood counties in north-central Texas, for measurement of $\mathrm{He}, \mathrm{Ne}, \mathrm{Ar}, \mathrm{Kr}$, and $\mathrm{Xe}$ concentrations and their respective isotopic ratios (Fig. 6).

Groundwater samples in the Trinity Aquifer are grouped into two clusters: one was the "south cluster", for samples taken near the Hood County and Parker County boundary, where high dissolved methane concentrations were previously documented and; and the second or "north cluster", as a background reference. DW-1 and DW-2 are located in the "south cluster", but were not included in the sampling program.

Following the classification of methane concentrations dissolved in groundwater by Eltschlager et al. (2001), only five groundwater samples all from the "south cluster" (samples 
$355,358,369,533$, and 555) display dissolved methane concentrations of concern, that is, $>10 \mathrm{mg} / \mathrm{L}$. The highest total ${ }^{4} \mathrm{He}$ concentrations were found in some of the south cluster wells with the highest methane concentrations (samples 355, $358,369,533$, and 555). In addition to being well correlated with dissolved methane in groundwater, concentrations of both total ${ }^{4} \mathrm{He}$ and crustal ${ }^{4} \mathrm{He}\left({ }^{4} \mathrm{He} *\right)$ are very similar and point to a dominantly crustal ${ }^{4} \mathrm{He}$ component in most samples, as opposed to atmospheric and mantle-derived components. The dissolved methane concentrations display positive correlations with multiple crustal noble gas isotopes - in particular, ${ }^{4} \mathrm{He}^{*},{ }^{21} \mathrm{Ne}^{*}$ and ${ }^{40} \mathrm{Ar} *$ - suggesting that noble gases and methane in the Trinity Aquifer originate from a common source.

To determine whether this external origin of methane and noble gases is the Strawn Group or the Barnett Shale and to assess whether or not the presence of stray gas results from a conventional or unconventional well, the ${ }^{20} \mathrm{Ne},{ }^{36} \mathrm{Ar},{ }^{84} \mathrm{Kr}$, and ${ }^{132} \mathrm{Xe}$ concentrations of Trinity Aquifer samples were examined (Fig.7). All four isotopes are introduced by the recharge of freshwater equilibrated with the atmospheric concentration of these isotopes so that they are saturated in groundwater.

In contrast to the data from most of the samples and as also previously documented by Darrah et al. (2014a, b) in a few water wells, four groundwater samples, all from the south cluster (samples 355, 358, 369, and 555) display ${ }^{20} \mathrm{Ne}$ and ${ }^{36} \mathrm{Ar}$ concentrations below the air-saturated water composition and point to significant depletion of atmospheric-derived ${ }^{20} \mathrm{Ne}$ and ${ }^{36} \mathrm{Ar}$ - that is, stripping of atmospheric noble gases. All four of these groundwater samples have high measured methane concentrations, between $\sim 12$ and $\sim 23 \mathrm{mg} / \mathrm{L}$.

If gaseous methane were present throughout the Trinity Aquifer, fractionation of atmospheric noble gas components in the water would be widely observed. Most water samples display minimal fractionation in ${ }^{132} \mathrm{Xe} /{ }^{36} \mathrm{Ar}$ and ${ }^{84} \mathrm{Kr} /{ }^{36} \mathrm{Ar}$ ratios; however, samples 555 and 358, with the highest methane concentrations did show significant fractionation, while samples 355 and 369, also with elevated methane concentrations, showed only minor fractionation. The observed fractionation in these four samples, which underwent stripping of all atmospheric noble gases, is consistent with water-gas phase interactions in a closed-system. A detailed analysis of driller log data available for these wells shows that all four of these wells are drilled through the unconformity into the Strawn Group that is likely to contain noncommercial gas accumulations. Heavy depletion of atmospheric noble gases and, in particular, of the heavier ${ }^{84} \mathrm{Kr}$ and ${ }^{132} \mathrm{Xe}$ in only these four wells is consistent with continuously sustained gas-phase methane migration from a nearby source. In addition, such source attribution is also supported by the findings of Wen et al. (2017) that noble gas signatures of stray gas samples from water wells mimic that of natural gas samples from the Strawn Group other than the Barnett Shale.
Wen et al. (2016) indicated that the fractionation level $F\left({ }^{132} \mathrm{Xe} /{ }^{36} \mathrm{Ar}\right)$, normalized to corresponding air values in water samples, was not correlated with distance to the nearest gas well, including both Barnett and non-Barnett wells. This lack of correlation reinforced the hypothesis that dissolved gas in wells with high methane content has a natural origin and likely migrates into the Trinity Aquifer from the Strawn Group. This mechanism is consistent with the lack of or minimal pressure and the microbial signature of the methane gas in the annular spaces of the two gas wells (GW-1 and GW-2).

Following the Wen et al. (2016) investigation, several companion studies were completed. Nicot et al. (2017) sampled 457 locations for dissolved methane across the Barnett Shale footprint and found that methane concentrations were generally low with 387 samples (84.7\%) having concentrations $<0.1 \mathrm{mg} / \mathrm{L}$; and $11(2.4 \%)$ have concentrations $>10 \mathrm{mg} / \mathrm{L}$, all in Parker and Hood counties. In addition, they indicated that there was a lack of correlation with distance to Barnett Shale horizontal wells and conventional wells, and with well density suggesting a natural origin for the dissolved methane, with the underlying Strawn Group of Paleozoic age as the main source of the dissolved gas. As with the Marcellus Shale studies of Osborn et al. (2011) and Jackson et al. (2013), the samples with the highest methane concentrations occurred within $1,000 \mathrm{~m}$ of an active gas well. The difference is that there was no increase in the concentration as the sample locations approached gas wells in the Nicot et al. (2017) investigation, while the highest concentrations in the Osborn et al. (2011) and Jackson et al. (2013) studies were noted in close proximity to gas wells ( $300-500 \mathrm{~m})$. In both cases, sampling biases appear to have been introduced which preclude robust statistical assessments of the relationship between methane concentrations and gas wells, since the greatest number of samples, with the highest concentrations of methane, were collected in two concentrated clusters; one in the Dimock area, where known methane migration has occurred, and the other in Parker County near GW-1 and GW-2 where it appears that the elevated methane levels have a natural origin.

Larson et al. (2018) compared dissolved nitrogen chemistry to the noble gas results of Wen et al. (2016) and in the same area as the Darrah et al. (2014a, b) investigation. One advantage of using nitrogen to differentiate between high and lowflux of stray natural gas into groundwater is that dissolved nitrogen is much less sensitive to change than dissolved methane due to the high concentration of nitrogen in atmosphericrecharged groundwater and the low concentration in natural gas.

Of the 457 groundwater wells in the Nicot et al. (2017) study, Larson et al. (2018) concentrated on 77 water wells (118 samples with replicates) in the 'Parker-Hood' cluster. Using two-component mixing models constructed with dissolved nitrogen concentrations and isotope values, they identified only three wells with high methane content (>10 mg/L), 


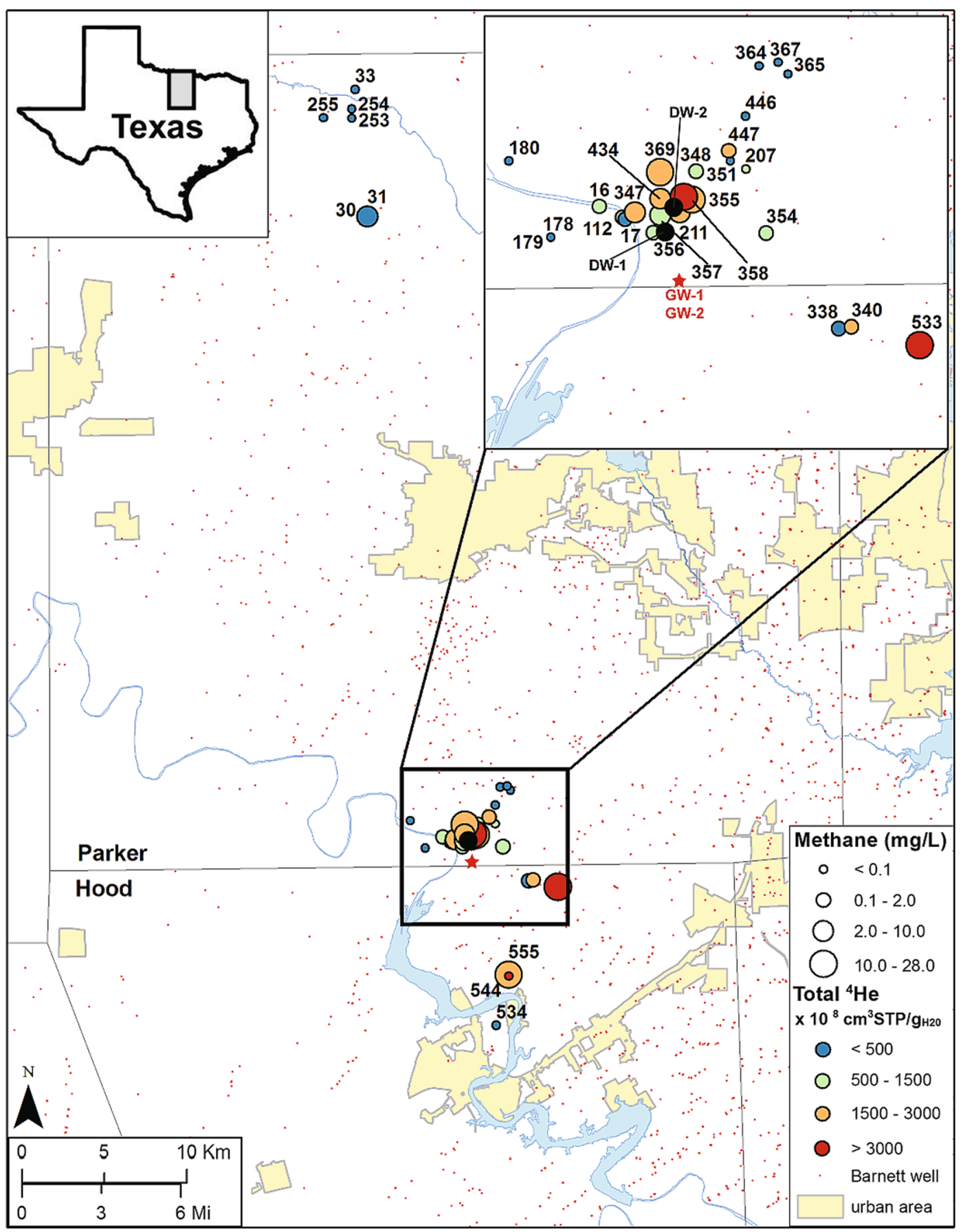

Fig. 6 Spatial distribution map of dissolved methane and total ${ }^{4} \mathrm{He}$ concentrations for sampled Trinity Aquifer wells at Parker-Hood County, Texas. Adapted from Wen et al. (2016), with permission from ACS Publications, and modified to include locations of gas wells GW-1

dissolved nitrogen concentrations $<11 \mathrm{mg} / \mathrm{L}, \delta^{15} \mathrm{~N}$ values lower than expected for atmospherically recharged groundwater, and gas:water ratios near 1.5 , that were likely affected by a large influx of natural gas, the same process as for the noble gases. Two of the wells (BS551 and BS 553) were in the same cluster that also included DW-1 and DW-2, near GW-1 and GW-2. and GW-2 and domestic water wells DW-1 and DW-2. DW-1 and DW-2 were not sampled by Wen et al. (2016) and the symbols for those wells only denote location

Larson et al. (2018) indicated that methane may have migrated to groundwater wells by localized transport of natural gas from the Strawn Group to the shallow groundwater aquifer that occurred during groundwater well drilling or that isolated shallow natural gas reservoirs within the Strawn Group may be in contact along an unconformity with the Trinity Group aquifer. As with the Wen et al. (2016) noble gas 

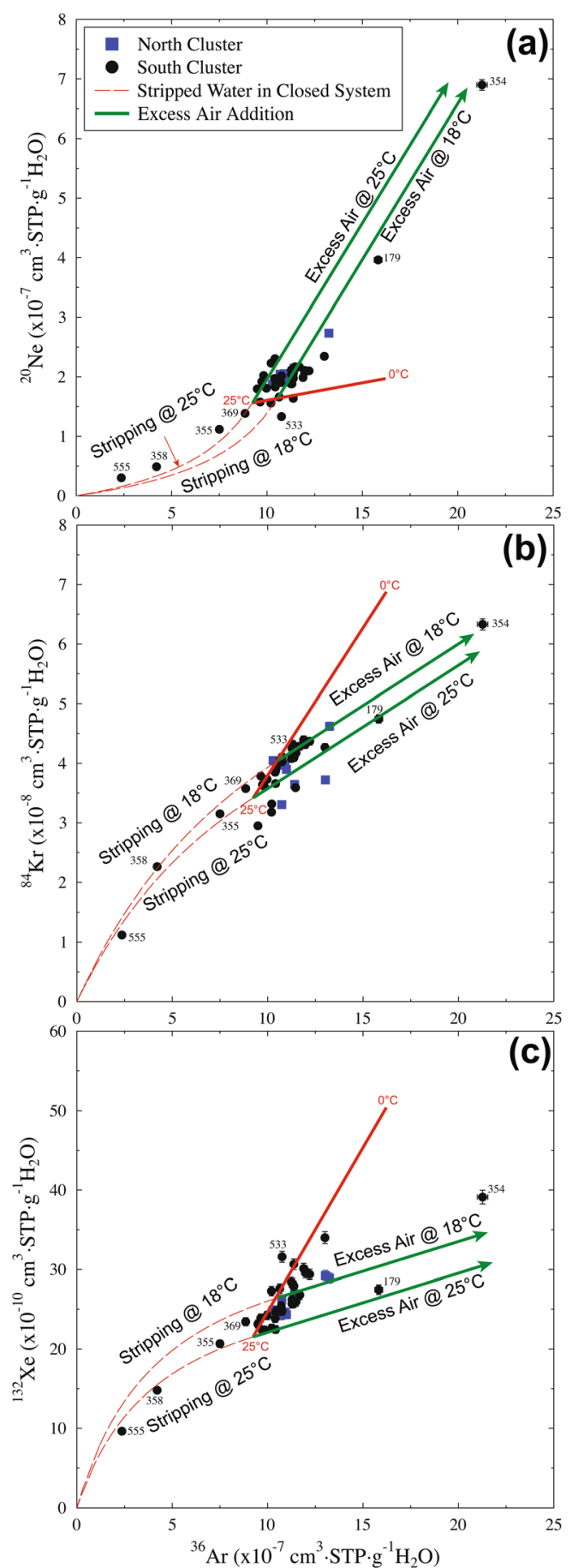

Fig. 7 a ${ }^{20} \mathrm{Ne}, \mathbf{b}{ }^{84} \mathrm{Kr}$ and $\mathbf{c}{ }^{132} \mathrm{Xe}$ concentrations as a function of ${ }^{36} \mathrm{Ar}$ concentrations for all collected Trinity groundwater samples. Predicted ${ }^{20} \mathrm{Ne},{ }^{36} \mathrm{Ar},{ }^{84} \mathrm{Kr}$ and ${ }^{132} \mathrm{Xe}$ concentrations in air saturated water (are shown for temperatures varying from 0 to $25{ }^{\circ} \mathrm{C}$ (red solid line). Predicted ${ }^{20} \mathrm{Ne},{ }^{36} \mathrm{Ar},{ }^{84} \mathrm{Kr}$, and ${ }^{132} \mathrm{Xe}$ concentrations in the water phase are also calculated for two scenarios: (1) addition of excess air (EA; green solid lines) and (2) residual water phase following water-gas interaction in a closed-system (red-dashed lines) at 18 and $25^{\circ} \mathrm{C}$ (reproduced from Wen et al. 2016 with permission from ACS Publications)

analyses, this scenario is supported by the lack of or minimal pressure and the microbial signature of the methane gas in the annular spaces of the two gas wells (GW-1 and GW-2) near the cluster of water wells in the study.

\section{Conclusions for the Parker County case study}

Based on the similar carbon-hydrogen isotope signatures of the production gas and the water wells near GW-1 and GW-2, the US EPA initially indicated that stray gas had migrated from the Barnett Shale in the Parker County incident. The nitrogen and carbon dioxide content of the water wells lead the TX RRC to determine that the source of the methane was the younger Strawn Group. Darrah et al. (2014a, b), using noble gas analyses, confirmed that Strawn Group was the methane source; however, unlike the TX RRC, they attributed the elevated methane concentrations to the release of annulus conducted gas. Thyne (2015) suggested that the methane had migrated during hydraulic fracturing from the Barnett Shale to the Strawn Group along a preexisting fault or hydraulically induced facture, although three-dimensional (3D) seismic modeling and surface maps indicate that there are no faults in the vicinity of GW-1 and GW-2. Wen et al. (2016) and the companion studies of Nicot et al. (2017) and Larson et al. (2018) used noble gas and dissolved nitrogen gas analyses to demonstrate that methane may have migrated to groundwater wells by localized transport of natural gas from the Strawn Group to the shallow groundwater Trinity Group aquifer that occurred during groundwater well drilling. The last scenario is supported by the high TOCs, lack of or minimal annular space pressures and the microbial signature of the methane gas in the annular spaces of the two gas wells (GW-1 and GW-2) near the cluster of water wells in the study area.

\section{Case study: Pavillion, Wyoming}

\section{Case study overview}

Pavillion (Fremont County, Wyoming) is located near the western end of the Wind River Basin. East of town, the Pavillion Field hosts 181 vertical gas wells that extract hydrocarbons from discontinuous sandstone units in the Fort Union and Wind River Formations. Gas, reported to have moved naturally into the Wind River Formation, is thought to be widespread below $153 \mathrm{~m}$ below ground surface (mbgs) according to the Wyoming Department of Environmental Quality (WYDEQ and AME 2015). In addition, several lines of evidence (DiGiulio and Jackson 2016) indicate that flow occurs naturally upward from the Fort Union to Wind River Formations. Nonetheless, $\sim 40$ domestic water wells extract water from the latter formation within the gas well field. The shallowest hydraulically fractured depth was $372 \mathrm{~m}$ and the deepest domestic well depth was 244 m (US EPA 2011). 
A number of homeowners complained of foul tastes and odors from their water wells, which led to starting an investigation in 2008 for 23 water wells. Domestic wells were sampled in 2009 and 2010. Two monitoring wells (MW01 and MW02) were also drilled and screened at about 235 and $295 \mathrm{~m}$ in 2010 in the US EPA study to determine if contaminants associated with hydraulic fracturing were moving upward.

In a draft report published in late 2011, the US EPA indicated that organic and inorganic geochemical anomalies, including very high $\mathrm{pH}$ readings in MW01 and MW02, were caused by hydraulic fracturing, and attributed the contamination in the domestic water wells tentatively to discharge of drilling and production fluids from unlined wastewater disposal ponds in the area. After numerous responses from state and federal officials, the oil and gas industry, consulting firms, and environmental groups, the US EPA decided in June 2013 not to finalize the draft report. Later, one of the former principal investigators was a coauthor of a peer-reviewed paper addressing many of the comments (DiGiulio and Jackson 2016). Here, this report briefly summarizes important points from DiGiulio and Jackson (2016) and the detailed reports by the consulting firms of Acton Mickelson Environmental, Inc., S.S. Papadopulos and Associates, Inc., and the Gradient Corporation. The incidents have remained controversial partly because many inferences were made from indirect measurements (e.g., well logs and reports) and because even the water quality data were subject to interpretation - for example, even though in the US EPA report it was argued that some analytes ( $\mathrm{pH}$, potassium, and/or chloride) in the deep monitoring wells were sometimes elevated by hydraulic fracturing activities, an alternative is that cement grout used in emplacing the monitoring wells caused the contamination. Specifically, without a bentonite seal in the monitoring wells, $\mathrm{K}$ - and Cl-containing cement may have flowed past the well screen and may have caused high $\mathrm{pH}$ values.

Other examples of competing explanations include those for BTEX compounds (benzene, toluene, ethyl benzene and xylene) that were found only in MW02, while other petroleum-based organics were found in both monitoring wells. These compounds correspond to additives or compounds sometimes associated with hydraulic fracturing. Similar compounds were found in a sample of Pavillion gas from well condensate collected by the US EPA; thus, these compounds may alternately have come from a natural source in the area. On the other hand, some synthetic organic compounds were found in one or both of the monitoring wells, leading the US EPA to conclude that additives used during hydraulic fracturing or their breakdown products had contaminated the aquifer. Additional possibilities to explain the contamination include unreliability of the tests (e.g. for glycols) or natural breakdown of natural gas - (hydrocarbons, acetone, isopropanol, and tertiary butyl alcohol (TBA) - as a source for the organic compounds.

Figure 8, a modified cross-section of Fig. 20 in the US EPA (2011) report, was used by the US EPA to illustrate gas wells where bonding of cement between casing and geologic formation is inconsistent or cement is totally lacking (outside of production casings above stimulated intervals) that could have provided potential conduits for upward fluid and gas migration. Figure 9 illustrates the locations of the gas, monitoring and domestic wells, and the cross-section. In addition to the wells on the cross-section, the methane concentrations in all of the domestic wells were $<1 \mathrm{mg} / \mathrm{L}$. Relatively large depths to primary TOCs were reported in three wells with no cement bond $\log /$ variable density logs $(\mathrm{CBL} / \mathrm{VDL})$ : depths to primary TOC were reported for PF 41-11B, PF 12-12 and PF 33-12 as 274, 290 and $61 \mathrm{~m}$, respectively - supplemental data about well construction from DiGiulio and Jackson (2016). Figure 10 is a modified version of Fig. 18 of US EPA (2011) presenting isotope ratios and methane concentrations in the Pavillion study area. The methane concentrations of all 24 domestic wells in US EPA (2011) were $<1 \mathrm{mg} / \mathrm{L}$, while the average of the samples was 0.045 $\mathrm{mg} / \mathrm{L}$. The carbon and hydrogen isotopes also showed evidence of thermogenic gas that had undergone microbial oxidation. The similarity of the signatures of the stable isotopes of carbon and hydrogen in methane between production and monitoring wells suggest they have a common deep thermogenic source.

In addition, the Wyoming Oil and Gas Conservation Commission (WOGCC 2014) tested the nearest gas wells (PF 12-12, PF 13-12 and PF 13-12) to MW02 (within $300 \mathrm{~m}$ ) and they passed bradenhead tests; i.e., no pressure was detected in the annuli at the land surface. Also, near MW01, shut-in pressure tests of TP 31-10 and TP 41-10B sustained the relatively low pressures of $193 \mathrm{kPa}$ (28 psi) and $1,186 \mathrm{kPa}(172 \mathrm{psi})$, respectively, after 7 days. DiGiulio and Jackson (2016) presented the results of analyses of tubing string production gas and bradenhead samples for 25 wells that had sustained casing pressure.

DiGiulio and Jackson (2016) argued that contaminants and groundwater are migrating in an upward and lateral direction because the concentrations of organic compounds were higher in the deeper monitoring well (MW02) and breakdown products were more concentrated in the shallower well (MW01). The presence of a few flowing domestic and gas wells were offered as evidence of upward groundwater flow in the well field but some contradictory evidence was also cited and no detailed regional mapping of groundwater levels and hydraulic gradients were reported.

DiGiulio and Jackson (2016) list 11 gas wells that had lost zonal control as further evidence of contamination of the aquifer by production wells; however, only one of those wells was within $600 \mathrm{~m}$ of a monitoring well. A casing failure had been 
Fig. 8 Lithological cross-section along transect through Pavillion study area, showing profiles of production wells, domestic wells, monitoring wells MW01 and MW02, and depths of hydraulic fractures, with evaluations of CBLs/VDLs (adapted from US EPA 2011, and adds the methane concentrations of the domestic and monitoring wells)

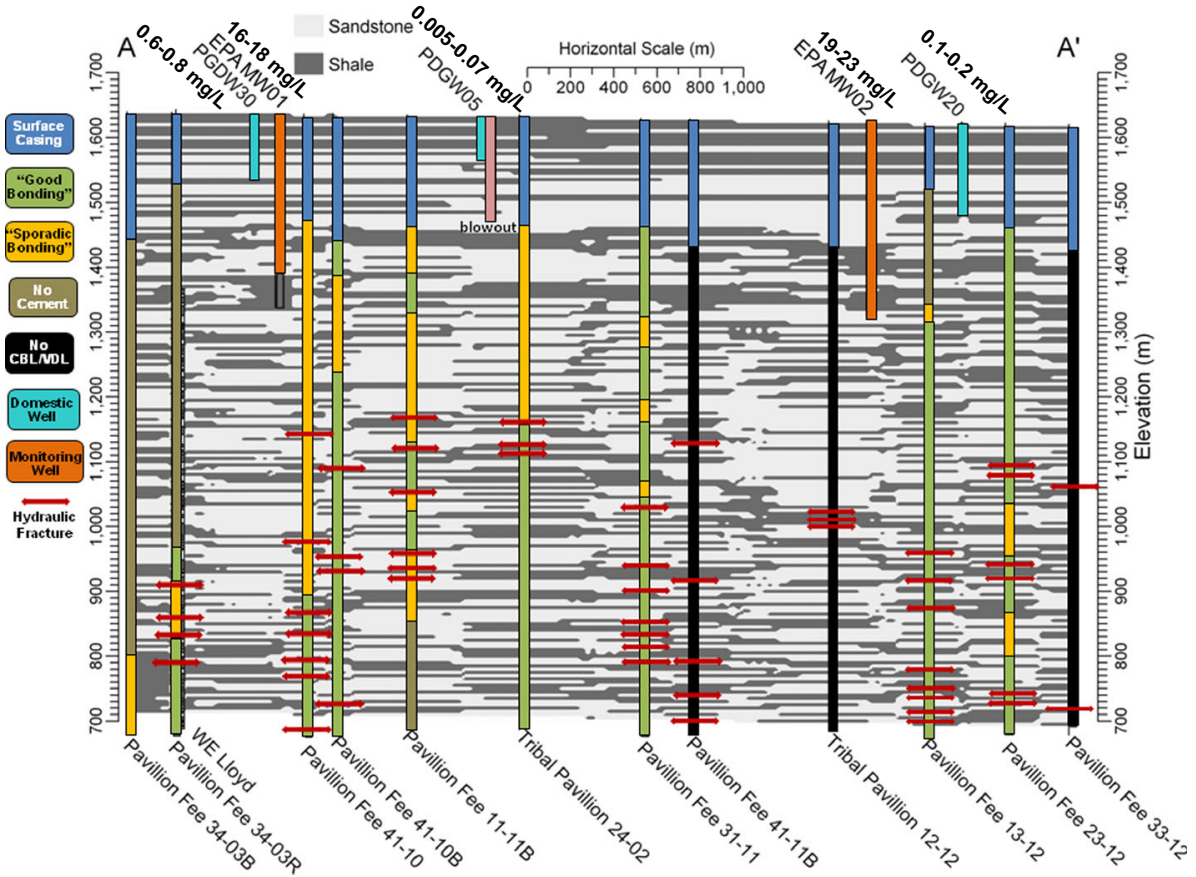

MW02, was squeezed in 2005. The squeeze was performed at $259 \mathrm{~m}$, indicating there was an undefined well issue above reported in unit 41X-10, near MW01, leading to plugging and abandonment in 1981. Tribal Pavillion well 12-12, near

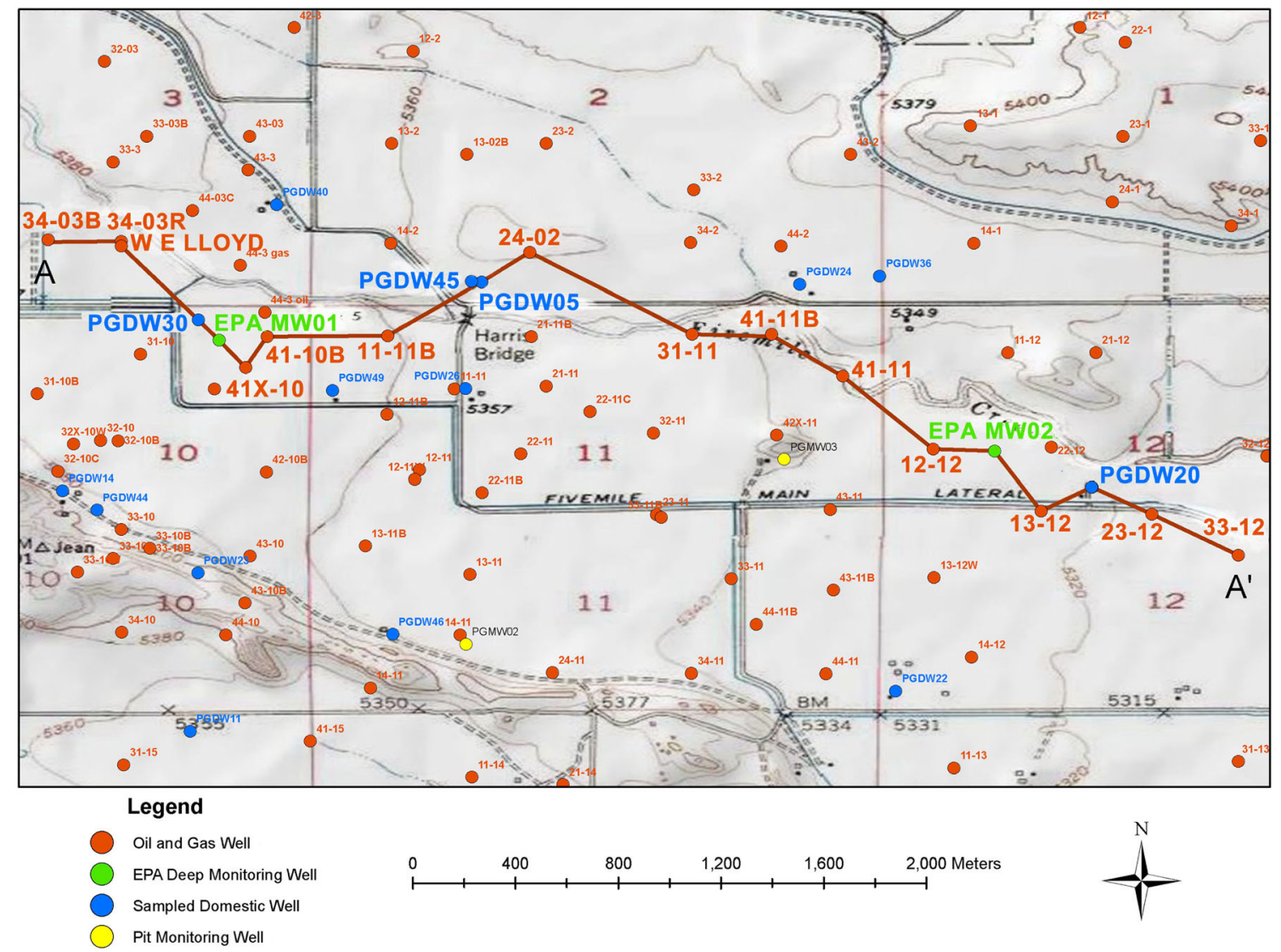

Fig. 9 Map of the Pavillion study area, Wyoming, illustrating locations of oil and gas wells, domestic water wells, monitoring wells MW01 and MW02, and the transect (orange line) of the lithological cross-section shown in Fig. 8 (reproduced from US EPA 2011) 
Fig. 10 Isotope ratios and methane concentrations in the Pavillion study area. a Stable isotope ratios of carbon versus hydrogen of samples taken from selected production and domestic wells, and MW01 and MW02. b

Methane concentration of domestic and monitoring wells relative to distance from production wells and elevation above mean sea level (AMSL). Adapted from US EPA 2011, to include identification of domestic and monitoring wells included in the lithological cross-section (Fig. 8) and map (Fig. 9); includes citation of Johnson and Rice 1993
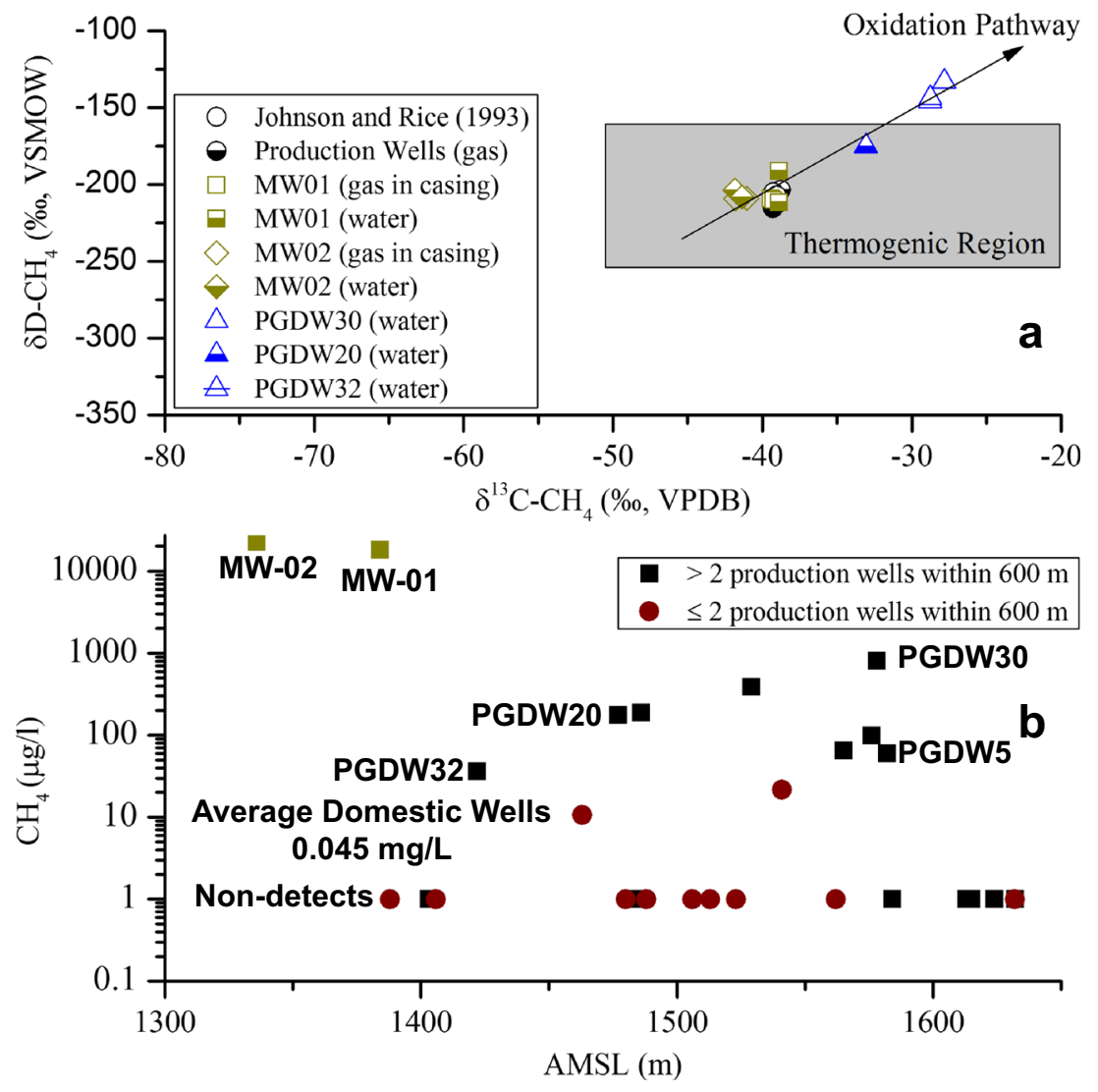

the TOC (309 $\mathrm{m}$ above the first producing zone) that was most likely due to shallow gas migration.

DiGiulio and Jackson (2016) reported that water flowed to the surface during bradenhead testing at four production wells. None were within $600 \mathrm{~m}$ of either monitoring well and the closest was Pavillion Fee well 12-11 W (PF 12-11 W), located about $925 \mathrm{~m}$ southeast of MW01. Pressure testing on PF 12$11 \mathrm{~W}$ indicated that water flowed outside the production casing. Cement squeezes were then performed at $146 \mathrm{~m}$ and $442 \mathrm{~m}$ on May 17, 2013 to stop the flow. This indicates that the source of the water was at least $177 \mathrm{~m}(580 \mathrm{ft})$ above the primary TOC and $329 \mathrm{~m}(1,080 \mathrm{ft})$ above the top perforation, consistent with flow from a shallow zone and that was not related to hydraulic fracturing.

Water flowing from the annular space of Tribal Pavillion 13-1 (TP 13-1) had a pH of 10.86, which the DiGiulio and Jackson (2016) indicated was evidence of elevated $\mathrm{pH}$ above the zone of hydraulic fracturing. Since the primary TOC of TP 13-1 is unknown and no other information is available, it cannot be determined if flow in the annular space was due to hydraulic fracturing. However, TP $13-1$ is located about 1,265 m north of MW02 and 2980 m east of MW01, distances that make it improbable that TP 13-1 contaminated the monitoring wells. In addition, the gas wells nearest to MW01 and MW02 have produced water $\mathrm{pH}$ values between 5.9 and 8.5.
Another possibility is that the high $\mathrm{pH}$ in TP 13-1 was due to water interaction with cement.

DiGiulio and Jackson (2016) presented the results of analyses of tubing string production gas and bradenhead samples for 25 wells that had sustained casing pressure and offered that nearly all bradenhead gas samples were devoid of $\mathrm{CO}_{2}$ as other evidence of high $\mathrm{pH}$ above stimulation zones. One exception was well 12-5, which had concentrations of 99.5 and $0.05 \mathrm{~mol} \%$ for $\mathrm{N}_{2}$ and $\mathrm{CO}_{2}$, respectively; possibly from a near surface source contaminated by nitrate fertilizer. Other than well 12-5, this would indicate that there was evidence of high $\mathrm{pH}$ in the remaining 24 wells above stimulation intervals; however, it seems unlikely that every well would have been affected by hydraulic fracturing. As opposed to the bradenhead samples, virtually all the string gas samples contained $\mathrm{CO}_{2}$. The two exceptions were well 12-5 and well 13-1, the latter of which had the anomalously high $\mathrm{pH}$. This gas may be a residual from the use of $\mathrm{CO}_{2}$ for stimulation or the produced gas may naturally contain a small amount of $\mathrm{CO}_{2}$. Otherwise, the composition of the string and bradenhead samples, including the alkane and BTEX compounds, are similar. If trace gases had migrated out of the target zone, this could explain some amount of $\mathrm{CO}_{2}$ in the samples. Since most of the $\mathrm{CO}_{2}$ in uncontaminated groundwater is from soil respiration, dissolution of $\mathrm{CO}_{2}$ from the atmosphere, natural 
oxidation of hydrocarbon gases and volcanic outgassing, it is possible that the absence of $\mathrm{CO}_{2}$ in the bradenhead samples reflects natural conditions at depth.

Nakamoto et al. (1986), in laboratory experiments, and Mercer et al. (2007), in a field study, demonstrated that the porewaters associated with cement initially start at circumneutral values but then increase above 12 and then return after a few years to near neutral. Continued monitoring of the $\mathrm{pH}$ values in samples from wells MW01 and MW02 could eventually provide evidence that the high $\mathrm{pH}$ in those wells was due to cement intrusion.

\section{Conclusions for the Pavillion case study}

The methane concentrations in all of the domestic wells were $<1 \mathrm{mg} / \mathrm{L}$ or an order of magnitude less than the lower level considered safe. The carbon and hydrogen isotope signatures were oxidized relative to those of the annular space and production gases. Relatively low pressures were measured during bradenhead tests, especially in gas wells near MW02. The presence of $\mathrm{CO}_{2}$ in samples from the tubing string and absence of $\mathrm{CO}_{2}$ in the bradenhead samples indicate two different sources and suggests that no out-of-zone migration or contamination by hydraulic fracturing fluids occurred. These factors are compelling evidence that stray gas migration did not occur at Pavillion.

With the exceptional amount of resources already at Pavillion, it might be worthwhile to look more closely at the construction details of the gas wells in the field, especially those near wells MW01 and MW02. This could include inspection of all well logs and operational reports, previous downhole logging, and all chemical analyses. Consideration should be given to running the most advanced cement evaluation logs, temperature and noise logging, and, if possible, conducting well interference tests. Also, the issue concerning BTEX and synthetic organic compounds might be addressed by sampling produced and bradenhead waters and gases.

\section{Case study: Sugar Run, Bradford County, Pennsylvania}

\section{Case study overview}

Contamination of six drinking water wells by natural gas along Paradise Road in the valley of the north branch of Sugar Run in southeastern Bradford County, Pennsylvania (Fig. 11) was described in 2015 (Llewellyn et al. 2015). Five gas wellpads with two wells each had been constructed between 2009 and 2010 at a location about 1 to $2.25 \mathrm{~km}$ north of the valley and problems at the water wells began in July 2010 . When problems started, only two of the gas wells on one of the wellpads (Welles 1) had been completed using HVHF. On
May 11, 2011, the Pennsylvania Department of Environmental Protection (PA DEP) presumed the gas company was responsible for gas migration into the aquifer. In addition, foaming in homeowner wells was noted but no determination by the PA DEP was made as to the cause. The water wells were cased to about $6.5 \mathrm{mbgs}$, and were left open down to a maximum of about $60 \mathrm{mbgs}$. Gas wells were all drilled into the Marcellus Shale Formation at depths of approximately $2 \mathrm{~km}$.

All the wells on the five wellpads (Welles 1-5) were constructed with surface casings (steel pipe with cement) to $300 \mathrm{~m}$ below ground surface (mbgs) on the vertical section, no casing at intermediate depths, and production casing through the zone of gas production from 2,100 to 2,300 mbgs (Fig.11). Multiple depth intervals of gas were encountered during drilling of the gas wells at intermediate depths where the boreholes were uncased (Figs. 12 and 13). This intermediate-depth gas may explain why the annular pressures on several of the gas wells exceeded regulation values $(24 \mathrm{~atm}, 2,413 \mathrm{kPa}$ or 350 psi) as summarized in Fig. 12.

High gas pressures led the gas company to remediate some of the gas wells with cement squeezes and plugs from Aug to Nov 2010 (Fig. 12); during that time period, gas bubbling was observed in the nearby Susquehanna River near the town of Sugar Run (town labelled on Fig. 11). One part of this cement squeeze included relatively shallow emplacement of large quantities of cement—for example, $31.2 \mathrm{~m}^{3}$ (196 barrels, bbl) of cement were pumped into a depth of 500-600 mbgs at Welles 3-2H (Fig. 11). As described in the following paragraphs, further issues continued in the homeowner wells.

The incident included both migration of stray gas as well as other contaminants, including measured concentrations of 2Butoxyethanol (2-BE). Llewellyn et al. (2015) concluded that the most likely cause was that natural gas was driven along with drilling or hydraulic fracturing fluids a distance of $1-$ $3 \mathrm{~km}$ through shallow to intermediate depth fractures or bedding plane openings into the water wells. They also implicated a major fault in the area as a possible pathway (Fig. 11). Possible alternative sources of the 2-BE were (1) a pit pond at the nearest well pad that had been cited for leakage of drilling fluids, (2) fluids used during drilling of one or more of the wells, or (3) leakage from hydraulic fracturing fluids during injection, i.e., on their way down (not returning from depth). An additional source for the 2-BE that was not cited by the original authors is the possibility that the large volume of cement used at shallow depth in the squeeze contained some 2-BE that was leached and mobilized in the groundwater.

The homeowners and gas company employed private consultants for sampling of water wells from July 2010 to May 2012. A lawsuit initiated by the homeowners was settled in June 2012: as a result, the gas company bought the properties and all data were released (Llewellyn et al. 2015). Through agreement with the PA DEP as a result of the 


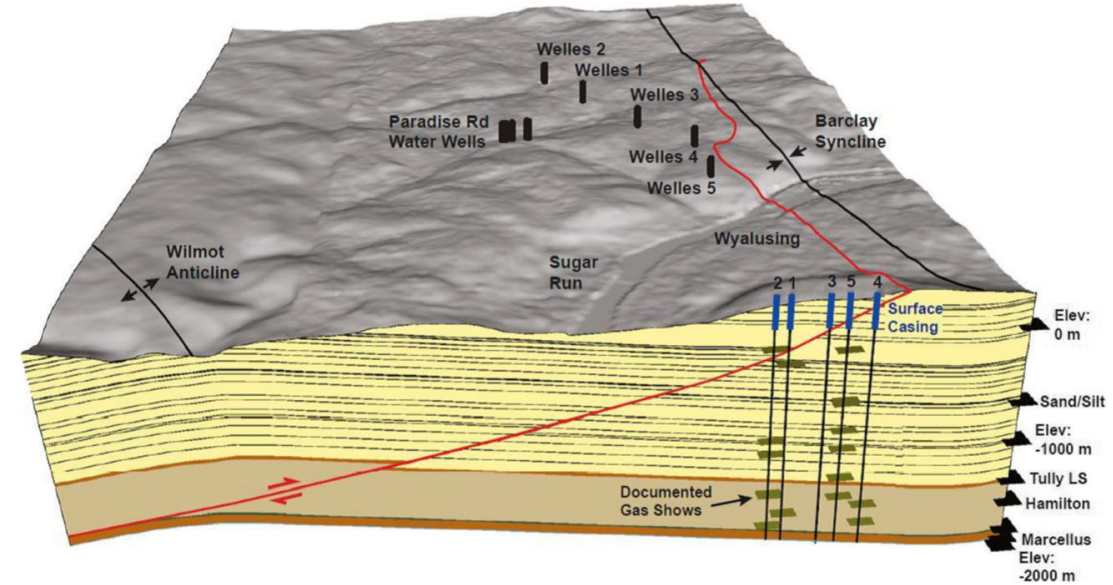

Fig. 11 Block diagram illustrating shallow angle thrust fault, structural fold surficial traces and bedding planes in the Sugar Run area, Pennsylvania. The positions of water wells 1-6 (Paradise Road) and gas wells Welles 1-5 series are shown with the gas wells projected to

litigation, the company was required to implement a threestring casing design for the Welles gas wells. Specifically, intermediate depth casing was to be emplaced for all the wells. PA DEP allowed the company to complete the gas wells on the remaining four pads (Welles 2-5) with HVHF between Nov 2012 and Sept 2013.

Llewellyn et al. (2015) reported analyses of samples of the homeowner wells from Nov 2012 where they analyzed the white foam with a technique not generally used by commercial analytical laboratories: comprehensive two-dimensional (2D) gas chromatography coupled to time-of-flight mass spectrometry. They compared the analyses to analyses of water from domestic wells outside of the impacted region and to the front of the block. In September 2010, gas was observed bubbling from the Susquehanna River, between the Wyalusing and Sugar Run communities, which ceased after the completion of gas well remedial activities (reproduced from Llewellyn et al. 2015)

$\sim 30$ flowback and production waters from gas wells completed with HVHF around Pennsylvania. They observed an unresolved complex mixture of organic compounds (UCM) in all flowback/production waters and in affected homeowner wells. A few of the flowback/production waters were also identified to contain 2-BE and glycols, compounds commonly used during drilling and HVHF. Nanogram/L level concentrations of 2-BE were identified in two of six water wells. 2-BE is the main compound, for example, in Airfoam, a commercial drilling additive and surfactant that had been in use in Pennsylvania and that can produce a white foam. 2-BE was assumed to be the cause of the foaming observed by the homeowners.
Fig. 12 Schematics illustrating construction of gas wells Welles 1-5 series at Sugar Run, with depth intervals of gas shows, remedial activities (squeezes and plugs), originally (primary) emplaced cement and "partially bonded" cement. Highest recorded gas well annular pressures are included (reproduced from Llewellyn et al. 2015)

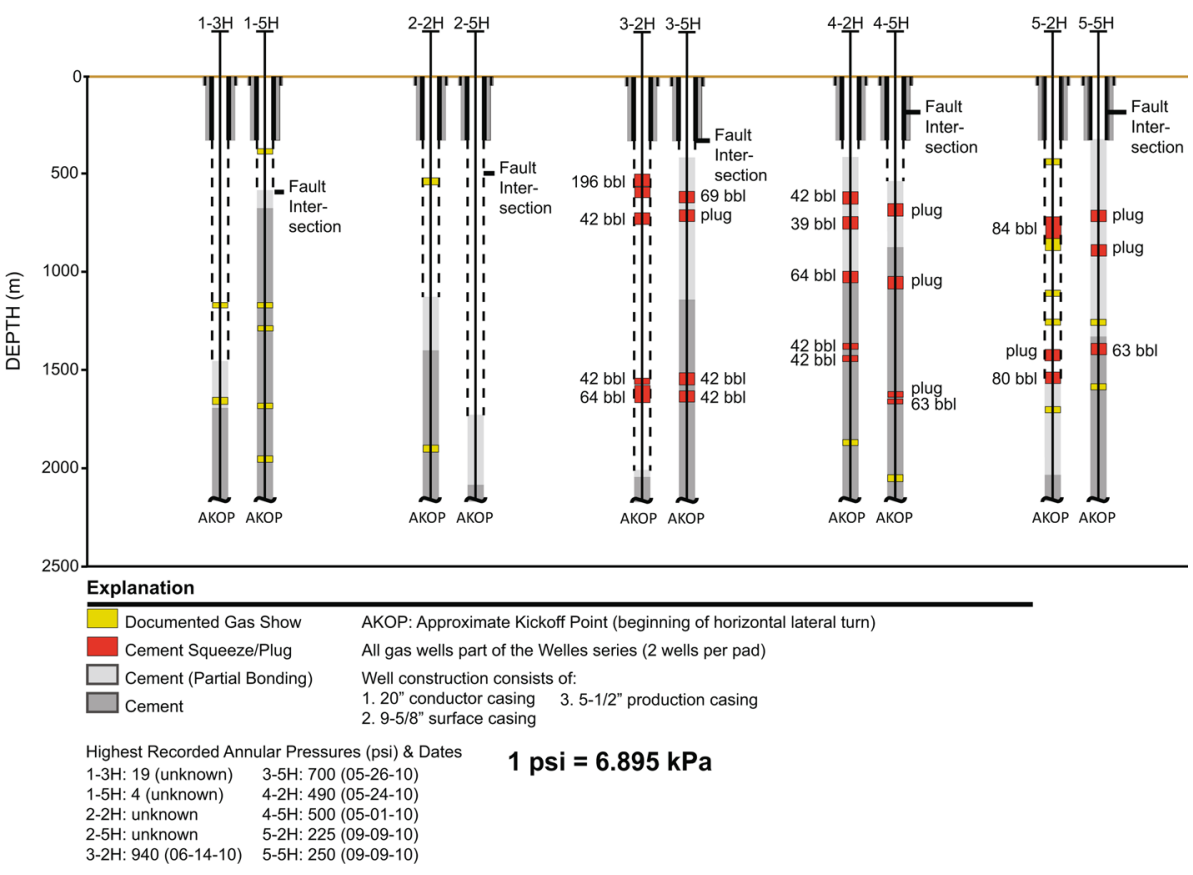


Fig. 13 Stable isotope ratios of carbon versus hydrogen for samples taken from the annular spaces of gas wells (Welles 2-5) and impacted domestic water wells (1, 3 and 5) for which data exist. Predrill private well data were collected in Bradford, Sullivan, Susquehanna and Tioga counties, NE Pennsylvania (reproduced from Llewellyn et al. 2015)

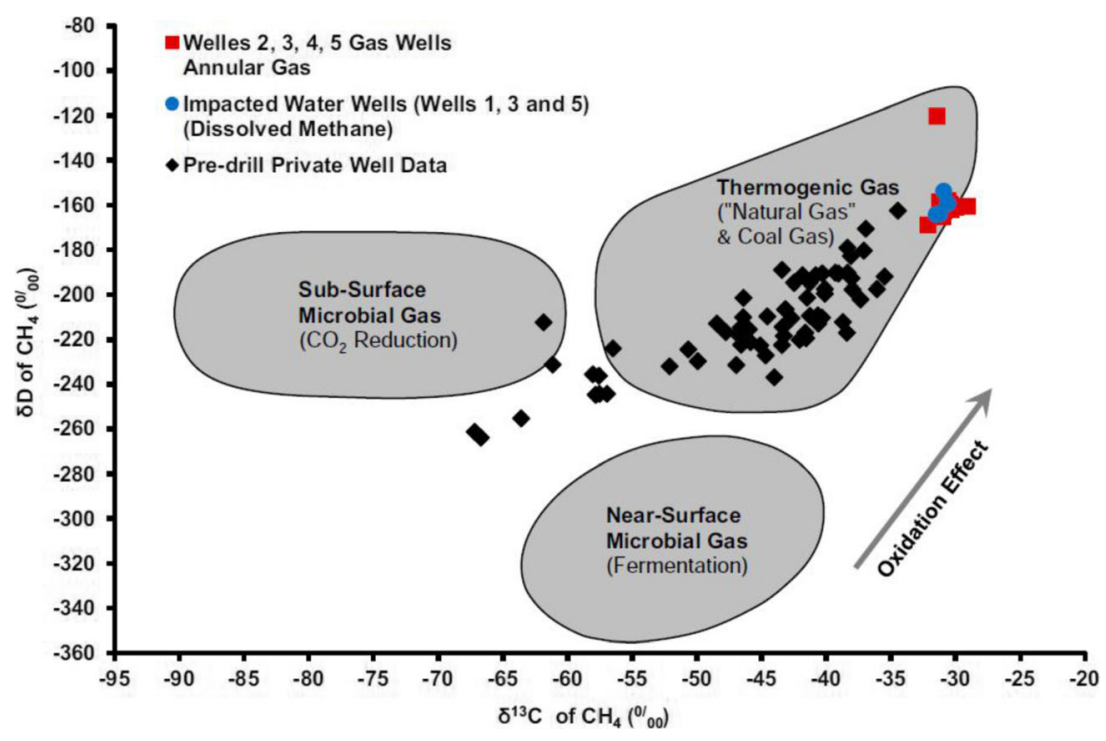

Methane and ethane data (concentrations and isotopic signatures) are summarized by Llewellyn et al. (2015) for homeowner wells and for gas wells. Between 2010 and 2012, methane concentrations in waters from homeowner wells were as high as $46.6 \mathrm{mg} / \mathrm{L}$ (much higher than the only predrill measurement, $<0.02 \mathrm{mg} / \mathrm{L}$ ). Methane concentrations in one of the homeowner wells generally decreased after remediation of Welles 3, 4, and 5. In addition, the isotopic signature of sampled gas in homeowner wells matched those reported for annular gases in Welles 2-5, and differed from nonimpacted groundwaters (Fig. 13). While Llewellyn et al. (2015) did not discuss the depth of origin of the fugitive gas directly, they indicated that no samples of HVHF or flowback/production water from the Welles-series wells were available. Figure 13 of Llewellyn et al. (2015) also shows that the gas in gas well annuli, with one exception, was isotopically similar to Marcellus gas (production gas) when compared to published data for the area (Molofsky et al. 2011; Llewellyn et al. 2015; Baldassare et al. 2014). There is, however, a considerable statistical overlap in the isotopic signatures of the Tully Limestone and Mahantango Shale with the Marcellus Formation, including a so-called isotopic reversal seen in all those units; consequently, Baldassare et al. (2014) cautions against applying average regional isotopic values to sitespecific natural gas occurrences. The relatively high gas well primary TOCs and squeeze cementing of shallow and intermediate intervals could also point to a methane source within $500 \mathrm{~m}$ above the Marcellus Shale. Llewellyn et al. (2015) concluded that gas migrated from Welles $3-2 \mathrm{H}$ on the Welles pads because of excessive annular pressures in the borehole ( $\sim 64 \mathrm{~atm})$. Other wellpads in the Welles series may also have leaked. The gas migration may also have influenced the movement of the 2-BE.

\section{Conclusions for the Sugar Run case study}

The high methane concentrations and the match to the gas well annular space isotopic signatures of the water wells and elevated pressures in the gas wells indicate that stray gas migration occurred. Isotope results were consistent with movement of stray gases, moving upward from a depth of at least $1,500 \mathrm{~m}$ along the uncased and uncemented intermediate depths into a large regional fault and moving along local bedding plane openings. Additional sampling of production gases for $\mathrm{C}-\mathrm{H}$ isotopes, and annular space, production and water well gases for noble gas, dissolved nitrogen gas and $\mathrm{CO}_{2}$ gas analyses and presenting the results of any tests of the mechanical integrity of the gas wells might have helped determine the exact depth of the source of the stray methane. The movement of gas could have influenced the movement of the 2-BE, a drilling fluid-, cement-, or hydraulic fracturing-related contaminant that is also used in industrial solvents.

\section{Discussion}

The case studies presented here or summarized in the ESM indicate that there were various causes of methane migration. The most obvious was that there were substantial lengths of (open-hole) production casings in boreholes that were uncemented or that there were boreholes that were not cased at intermediate depths and were thus left uncemented, leading to methane migration from gas-charged nonproducing zones into intermediate depths, or movement of gas from above-target formations. This occurred at multiple sites in Dimock, Sugar Run, and possibly at Shaws Corner, PA, and the 
Parson's well in West Virginia. Three had low primary TOC $(<100 \mathrm{ft}, 30.5 \mathrm{~m})$ associated with lost circulation events, which could have led to out-of-target-zone migration of production gases. In Dimock GW-1, the isotopic signature of gas in the annular space was consistent with that of the shallow Mahantango Shale, from which $17 \mathrm{Mm}^{3} /$ day of flowing gas was reported. Limited chemical data (elevated Fe levels in two nearby house wells) suggest that methane migration may have occurred prior to hydraulic fracturing. At two other sites in Dimock, methane concentrations became elevated after drilling but before hydraulic fracturing. At Bainbridge, $\mathrm{OH}$, the low TOC may have allowed a small amount of the oil and brine fluids used during hydraulic fracturing to return to the surface through the annular space of the gas well (ESM). About one month later a blow-out and house explosion occurred. The methane may have migrated from the target formation; however, no isotope analyses were performed that could confirm the source. At the Mamm Creek Field/West Divide Creek site, CO, the subject gas well had a low TOC and the isotopic signatures of the production, annular space and creek/monitoring wells were similar. This would suggest a common source unless there is a hydraulic connection between deep target and shallow nonproductive formations. Such a connection was evident at the Parker County site; however, the annular space isotopes had the characteristics of a shallow biogenic source and noble gas and dissolved nitrogen analyses indicated that the potentially impacted water wells had been drilled into the shallow, gas-charged Strawn Group. At Pavillion, the absence of $\mathrm{CO}_{2}$, which was a residual in production gases as a result of hydraulic fracturing, in bradenhead samples is most consistent with natural conditions at depth (rather than contamination). The deep Fort Union and shallower Wind River formations had similar isotope ratios; however, the maximum concentration of methane in water wells was less than $1 \mathrm{mg} / \mathrm{L}$, suggesting that there was no significant impact due to methane migration. The isotopic signatures of the methane from the Sugar Run gas well annular spaces and water wells were similar, and about the same as regional average Marcellus values; however, the relatively high primary TOCs and intermediate and shallow squeezes suggest that the methane could have migrated from intermediate level Middle Devonian formations. The ultimate source of the thermogenic gas could have been determined by sampling of production gases, noble gas/dissolved nitrogen $/ \mathrm{CO}_{2}$ analyses, and well integrity testing.

In the cases where squeeze cementing was performed, fewer than half of the procedures appear to have been fully successful. Others were partially successful in mitigating some but not all of the impacts to private wells. Four wells (GW-1, GW-3, GW-3a and GW-3b) were plugged and abandoned in Dimock. Methane concentrations in nearby water wells were reduced to safe levels after abandonment of one gas well (GW-1). At Dimock well pad 3, all three gas wells were plugged, with the impacts in only one of four water wells mitigated. At Dimock site 3, the C-H isotope analyses indicate a deep source (Mahantango-Tully formations) of the migrated gas, suggesting that the deep gas well (GW-3a) may have caused the impacts. It is not clear if the shallow gas wells at that site provided a portion of the pathway for the methane contamination. The squeeze cement seals for the English 1 well in Bainbridge (ESM) reduced, but did not eliminate the elevated methane levels in the nearby house wells. The squeeze remediation procedure on the Swartz 2-15B (02) well in the Mamm Creek Field partially reduced but did not eliminate the high concentrations of methane or benzene in the monitoring wells and West Divide Creek (ESM). The benzene levels in West Divide Creek were primarily reduced by a shallow "surge" recovery and treatment system. Finally, in none of these studies was there clear evidence of leakage of fugitive gases due to production casing failures or clear evidence of contamination of water wells by hydraulic fracturing fluids.

\section{Conclusions}

This report presents the results of the relatively few, detailed, site-specific studies that have addressed methane migration related to the hydraulic fracturing of shale-gas wells. They do not necessarily provide evidence of widespread regional problems. The actual scope of the problem is difficult to demonstrate, since impacts to water supplies due to migration of fugitive gases are often adjudicated between operators and homeowners involving nondisclosure agreements. In the cases presented in this report, the primary causes of methane migration were uncemented sections of production casings providing conduits for gas flow most likely from intermediate, generally nonproducing zones, to shallow aquifers. As a secondary factor, several gas wells also lost circulation and this ultimately led to inadequate TOCs that were too low.

These results yield evidence that could improve the methods for preventing, detecting and mitigating impacts associated with methane migration. The collection of predrilling samples is the best way to determine if methane concentrations increase after drilling or hydraulic fracturing. A secondary method is to collect samples before and after venting of gas wells. Forensic methods are the best way to determine sources of fugitive gases. For initial investigations, isotope analyses (carbon, hydrogen) of gas samples from production casing, the annular space and water wells should be conducted. If there is the possibility of cross-formation flow between target and intermediate 
formations such as in Parker County and Pavillion, analysis of noble gas stable isotopes should be completed. Carbon dioxide and nitrogen analyses could be used to differentiate between near-surface and deep water sources. These methods should be used in conjunction with downhole well logging and mechanical integrity testing. Geological mapping is inherently useful to constrain pathways or sources. In the cases presented, the impacts may have been prevented by relatively low-cost primary cementation of the full lengths of the production casings to extend upward to the inside of intermediate casing strings or to the surface, if there is no intermediate casing installed. Remediation of gas wells with secondary cement squeezes at the various sites was only successful in some cases. Finally, sitespecific studies on the long-term fate of the integrity of wellbore systems do not appear to exist. It has been about 10 or more years since the impacts in the studies presented in this review occurred. Some of the gas wells appear to still be in service and should be considered for additional study to determine if the effects of the fugitive gases have dissipated or that additional well failures have occurred.

The cause of groundwater contamination in several settings has sometimes been attributed to hydraulic fracturing with very little proof. While this study did not address potential contamination by hydraulic fracturing fluids, this work demonstrated that in all the cases considered, gases cannot be proven to have escaped the target reservoir; rather, methane leaking into groundwater related to these wells probably originated higher up in the stratigraphic/geological section, mainly from uncemented or poorly cemented portions of the well.

Acknowledgements The editor Dr. Jean-Michel Lemieux, an anonymous associate editor, Dr. Thomas H. Darrah and one anonymous reviewer, and the technical editorial advisor Sue Duncan, provided many useful comments and suggestions that greatly improved the content and organization of the manuscript. Dr. Jean-Philippe Nicot made useful comments on an early version of the manuscript. The views expressed in this report do not necessarily reflect the views or policies the Maryland Department of the Environment.

Funding information Funding for S.L.B. and T.W. was derived from grant IIS-16-39150 to S.L.B. from the National Science Foundation. T.W. was also supported by the College of Earth and Mineral Sciences Dean's Fund for Postdoc-Facilitated Innovation at the Penn State University.

Open Access This article is licensed under a Creative Commons Attribution 4.0 International License, which permits use, sharing, adaptation, distribution and reproduction in any medium or format, as long as you give appropriate credit to the original author(s) and the source, provide a link to the Creative Commons licence, and indicate if changes were made. The images or other third party material in this article are included in the article's Creative Commons licence, unless indicated otherwise in a credit line to the material. If material is not included in the article's Creative Commons licence and your intended use is not permitted by statutory regulation or exceeds the permitted use, you will need to obtain permission directly from the copyright holder. To view a copy of this licence, visit http://creativecommons.org/licenses/by/4.0/.

\section{References}

Baldassare FJ, McCaffrey MA, Harper JA (2014) A geochemical context for stray gas investigations in the northern Appalachian Basin: implications of analyses of natural gases from Neogene- through Devonian-age strata. AAPG Bull 98(2):341-372. https://doi.org/ 10.1306/06111312178

Darrah TH, Vengosh A, Jackson RB, Warner NR, Poreda RJ (2015) Noble gases identify the mechanisms of fugitive gas contamination in drinking-water wells overlying the Marcellus and Barnett shales. Proc Natl Acad Sci 111(39):14076-14081. https://doi.org/10.1073/ pnas.1322107111

Darrah TH, Jackson RB, Vengosh A, Warner NR, Whyte CJ, Walsh TB, Kondash AJ, Poreda RJ (2014) The evolution of Devonian hydrocarbon gases in shallow aquifers of the northern Appalachian Basin: insights from integrating noble gas and hydrocarbon geochemistry. Geochim Cosmochim Acta 170:321-355. https://doi.org/10.1016/j. gca.2015.09.006

DiGiulio DC, Jackson RB (2016) Impact to underground sources of drinking water and domestic wells from production well stimulation and completion practices in the Pavillion, Wyoming, field. Environ Sci Technol 50(8):4524-4536. https://doi.org/10.1021/acs.est. 5 b04970

Dusseault M, Jackson R (2014) Seepage pathway assessment for natural gas to shallow groundwater during well stimulation, in production, and after abandonment. Environ Geosci 21 (3):107-126. https://doi. org/10.1306/eg.04231414004

Dusseault MB, Jackson RE, Macdonald D (2014) Towards a road map for mitigating the rates and occurrences of long-term wellbore leakage. University of Waterloo and Geofirma Eng., Ottawa, ON. http:// geofirma.com/wp-content/uploads/2015/05/1wp-final-report compressed.pdf. Accessed 15 December 2018

Eltschlager KK, Hawkins JW, Ehler WC, Baldassare F (2001) Technical measures for the investigation and mitigation of fugitive methane hazards in areas of coal mining. US Dept. of the Interior Office of Surface Mining. https://semspub.epa.gov/src/document/05/936303. pdf. Accessed 15 March 2015

Engelder T, Zevenbergen JF (2018) Analysis of a gas explosion in Dimock PA (USA) during fracking operations in the Marcellus gas shale. Process Saf Environ Prot 117:61-66. https://doi.org/10.1016/ j.psep.2018.04.004

Frohlich C (2012) Two-year survey comparing earthquake activity and injection-well locations in the Barnett shale, Texas. Proc Natl Acad Sci 109(35):13934-13938. https://doi.org/10.1073/pnas. 1207728109

Gorody AW (2012) Factors affecting the variability of stray gas concentration and composition in groundwater. Environ Geosci 19:17-31. https://doi.org/10.1306/eg.12081111013

Hammond PA (2016) The relationship between methane migration and shale-gas well operations near Dimock, Pennsylvania, USA. Hydrogeol J 24(2):503-519. https://doi.org/10.1007/s10040-015$1332-4$

Jackson RB, Vengosh A, Darrah TH, Warner NR, Down A, Poreda RJ, Osborn SG, Zhao K, Karr JD (2013) Increased stray gas abundance in a subset of drinking water wells near Marcellus shale gas extraction. Proc Natl Acad Sci 110(28):11250-11255. https://doi.org/10. 1073/pnas. 1221635110

Johnson RC, Rice DD (1993) Variations in composition and origins of gases from coal bed and conventional reservoirs, Wind River Basin, 
Wyoming. In: Keefer WR, Metzger WJ, Godwin LH (eds) Oil and gas and other resources of the Wind River Basin, Wyoming. Wyoming Geological Association Special Symposium, 1993, pp 319-335. http://archives.datapages.com/data/wga/data/055/ 055001/319 wga0550319.htm. Accessed 10 December 2019

Kornacki AS, McCaffrey MA (2011) Composition, nature, and origin of produced gas, well headspace gas, and water solution gas samples; Parker County and Hood County, Texas. Weatherford Laboratories, Inc., Houston, Texas

Kornacki AS, McCaffrey M (2014) Monitoring the active migration and biodegradation of natural gas in the Trinity Group Aquifer at the Silverado Development in Southern Parker County, Texas. AAPG Annual Convention and Exhibition. http://www. searchanddiscovery.com/documents/2014/80395kornacki/ndx kornacki.pdf. Accessed 5 December 2018

Larson TE, Nicot JP, Mickler P, Castro MC, Darvari R, Wen T, Hall CM (2018) Monitoring stray natural gas in groundwater with dissolved nitrogen: an example from Parker County, Texas. Water Resour Res 54(9):6024-6041. https://doi.org/10.1029/2018wr022612

Li Z, You C, Gonzales M, Wendt AK, Wu F, Brantley SL (2016) Searching for anomalous methane in shallow groundwater near shale gas wells. J Contaminant Hydrol 195:23-30. https://doi.org/ 10.1016/j.jconhyd.2016.10.005

Li Z, You C, Gonzales M, Wendt AK, Wu F, Brantley SL (2017) Corrigendum to "searching for anomalous methane in shallow groundwater near shale gas Wells" (J. Contam. Hydrol. (2016) 195 (23-30) (S0169772216300985) (10.1016/j.Jconhyd.2016.10.005)). J Contam Hydrol 207:50-51. https://doi.org/10.1016/j.jconhyd. 2017.09.009

Llewellyn G, Dorman FL, Westland JL, Yoxtheimer D, Grieve P, Sowers T, Humston-Flumer E, Brantley SL (2015) A drinking water contamination incident attributed to Marcellus shale gas development. Proc Natl Acad Sci 112:6325-6330. https://doi.org/10.1073/pnas. 1420279112

Mercer JW, Erickson J, Slenska M (2007) Potential cross contamination due to drilling in source areas. Case study: Cabot Carbon/Koppers Superfund site, Gainesville, Florida. Geotrans, Sterling, VA, 22 pp

Molofsky LJ, Connor JA, Farhat SK, Wylie AS, Wagner T (2011) Methane in Pennsylvania water wells unrelated to Marcellus shale fracturing. Oil Gas J 109(19):54-93. https://www.ogj.com/1/vol109/issue-49/exploration-development/methane-in-pennsylvaniawater-full.html. Accessed January 2020

Molofsky LJ, Connor JA, Wylie AS, Wagner T, Farhat SK (2013) Evaluation of methane sources in groundwater in northeastern Pennsylvania. Groundwater 51(3):333-349. https://doi.org/10. 1111/gwat.12056

Molofsky LJ, Richardson SD, Gorody AW, Baldassare F, Connor JA, McHugh TE, Smith AP, Wylie AS, Wagner T (2018) Purging and other sampling variables affecting dissolved methane concentration in water supply wells. Sci Total Environ 618:998-1007. https://doi. org/10.1016/j.scitotenv.2017.09.077

Nakamoto DB, McLaren FR, Phillips PJ (1986) Multiple completion monitor wells. Groundw Monitor Remediat 6(2):50-55. https:// doi.org/10.1111/j.1745-6592.1986.tb01238.x

Nicot JP, Mickler P, Larson T, Castro MC, Darvari R, Uhlman K, Costley R (2017) Methane occurrences in aquifers overlying the Barnett shale play with a focus on Parker County, Texas. Groundwater 55(4):469-481. https://doi.org/10.1111/gwat.12508

Osborn SG, Vengosh A, Warner NR, Jackson RB (2011) Methane contamination of drinking water accompanying gas-well drilling and hydraulic fracturing. Proc Natl Acad Sci 108(20):8172-8176. https://doi.org/10.1073/pnas.1100682108

Pope P (2012) Parker County study. Railroad Commission of Texas (TX RRC), Site Remediation Section, Oil and Gas Division, 34 pp.
http://www.gwpc.org/sites/default/files/event-sessions/06Pope Peter.pdf. Accessed 5 December 2018

Pope P (2014) Water well complaint investigation report: Silverado on the Brazos Neighborhood, Parker County, Texas. Railroad Commission of Texas (TX RRC), 19 pp. https://www.scribd.com/document/ 228385751/Silverado-on-the-Brazos-Complaint-Investigation. Accessed 27 April 2019

Schoell M (1983) Genetic characterization of natural gases. AAPG Bull 67(12):2225-2238. https://doi.org/10.1306/ad46094a-16f7-11d7$8645000102 \mathrm{c} 1865 \mathrm{~d}$

Siegel DI, Azzolina NA, Smith BJ, Perry AE, Bothun RL, (2015) Methane concentrations in water wells unrelated to proximity to existing oil and gas wells in Northeastern Pennsylvania. Environ Sci Technol 49 (7):4106-4112. https://doi.org/10.1021/es505775c

Thyne G (2015) Determination of the source of natural gas in water wells: an example from Parker County, Texas. Science Based Solutions, Laramie, WY. https://www.researchgate.net/publication/ 279531893. Accessed January 2020

TX RRC (2011) Oil and Gas Docket no. 7B-0268629. Revised examiner's report and proposal for decision, March 11, 2011. Office of General Counsel, Railroad Commission of Texas (TX RRC). https:// www.rrc.state.tx.us/media/10502/7b-68629rangepfd-03-11-11commcalledepa.pdf. Accessed 21 May 2019

US EPA (2011) Investigation of ground water contamination near Pavillion, Wyoming: draft report. US EPA, Office of Research and Development, National Risk Management Research Laboratory, Ada, OK and Region 8, Denver CO. http://www2.epa.gov/ region8/draft-investigation-ground-water-contamination-nearpavillion-wyoming. Accessed 11 January 2019

US EPA (2012) Dimock residential groundwater site, Dimock PA-US EPA region III (molecular and isotopic data). US EPA. http:// www.epaosc.org/site/doc_list.aspx?site_id=7555. Accessed 6 April 2014

US EPA (2016) Hydraulic fracturing for oil and gas: impacts from the hydraulic fracturing water cycle on drinking water resources in the United States. EPA-600-R-16-236Fa, US EPA, Office of Research and Development, Washington, DC. www.epa.gov/hfstudy. Accessed 22 January 2019

Vidic RD, Brantley SL, Vandenbossche JM, Yoxtheimer D, Abad JD (2013) Impact of shale gas development on regional water quality. Science 340(6134):1235009. https://doi.org/10.1126/science. 1235009

Watson RW (2010) White paper and full report. Cabot Oil \& Gas Corporation, Houston, TX. http://www.cabotog.com/pdfs/Data Presentation_DEP.pdf. Accessed 7 May 2014

Watson T, Bachu S (2008) Identification of wells with high CO2-leakage potential in mature oilfields developed for $\mathrm{CO} 2$-enhanced oil recovery. SPE 112924, Society of Petroleum Engineers, Richardson, TX. https://doi.org/10.2118/112924-ms

Watson T, Bachu S (2009) Evaluation of the potential for gas and CO2 leakage along wellbores. SPE Drill Complet 24(1):115-126. SPE 106817. https://doi.org/10.2118/106817-pa

Wen T, Castro MC, Nicot JP, Hall CM, Larson T, Mickler P, Darvari R (2016) Methane sources and migration mechanisms in shallow groundwaters in Parker and Hood counties, Texas: a heavy noble gas analysis. Environ Sci Technol 50(21):12012-12021. https://doi. org/10.1021/acs.est.6b01494

Wen T, Castro MC, Nicot JP, Hall CM, Pinti DL, Mickler P, Darvari R, Larson T (2017) Characterizing the noble gas isotopic composition of the Barnett Shale and Strawn Group and constraining the source of stray gas in the Trinity Aquifer, North-Central Texas. Environ Sci Technol 51 (11):6533-6541. https://doi.org/10.1021/acs.est. $6 \mathrm{~b} 06447$

Wen T, Niu X, Gonzales M, Zheng G, Li Z, Brantley SL (2018) Big groundwater data sets reveal possible rare contamination amid otherwise improved water quality for some analytes in a region of 
Marcellus shale development. Environ Sci Technol 52(12):71497159. https://doi.org/10.1021/acs.est.8b01123

Woda J, Wen T, Oakley D, Yoxtheimer D, Engelder T, Castro MC, Brantley SL (2018) Detecting and explaining why aquifers occasionally become degraded near hydraulically fractured shale gas wells. Proc Natl Acad Sci 115(49):12349-12358. https://doi.org/ 10.1073/pnas.1809013115

WOGCC (2014) Pavillion Field well integrity review. Pavillion Working Group, Wyoming Oil and Gas Conservation Commission (WOGCC), 96 pp. http://wogcc.state.wy.us/pavillionworkinggrp/ 08062014/PavillionWellIntegrityReviewReport.pdf. Accessed 5 May 2019
Wojtanowicz AK, Nishikawa S, Rong, X (2001) Diagnosis and remediation of sustained casing pressure in wells. Final report, Louisiana State University, Virginia. US Department of Interior, Minerals Management Service. http://wellintegrity.net/Documents/MMSDiagnosisofSCP-2001-07-31.pdf. Accessed 15 December 2018

WY DEQ, AME (2015) Pavillion, Wyoming domestic water wells draft final report and palatability study. Wyoming Department of Environmental Quality WY DEQ) and Acton Mickelson Environmental. http://deq.wyoming.gov/media/attachments/ WaterQuality/PavillionInvestigation/DraftReport/01 PavillionWYAreaDomesticWaterWellsDraftFinalReport.pdf. Accessed 12 December 2019 